Please cite as:

Louagie, Dana \& Jean-Christophe Verstraete. 2015. Personal pronouns with determining functions in Australian languages. Studies in Language 39: 158-197. 


\begin{abstract}
This paper analyses the adnominal use of personal pronouns in a sample of 75 Australian languages. We develop two arguments. First, we argue that in all of the adnominal uses examined, the personal pronoun has a determiner-like function, showing both the functional properties and some of the behaviour of more typical determiner categories like demonstratives or articles. We support this analysis with evidence from positioning tendencies, semantics and discourse functions, and indications of grammaticization in some languages. Secondly, we show that this phenomenon is relatively widespread in Australia, occurring in about half of the languages examined here. We identify five potential geographic clusters, one or two of which can be analysed as areally determined groupings around a centre with incipient grammaticization. From a typological perspective, these data present new evidence for a somewhat under-studied pathway to nominal determination, in addition to better-studied pathways involving demonstratives, numerals or adjectives.
\end{abstract}




\section{Personal pronouns with determining functions in Australian languages}

Dana Louagie \& Jean-Christophe Verstraete

University of Leuven

\section{Introduction $^{1}$}

This paper analyses the adnominal use of personal pronouns in Australian languages, illustrated in the structures in (1)-(2) below. In both of these cases, the pronoun does not establish reference independently from the nominal, but serves as a modifier for the nominal, providing information about definiteness and/or specificity (see Wilkins 1989: §3.7.3, Evans 2003a: 245-247).

(1) Mparntwe Arrernte (Wilkins 1989: § 3.7.3)
artwe itne no ahel-irre-ke
artwe mperlkere ikwere
man 3PL.S no angry-INCH-PST.COMPL man white 3 SG.DAT $^{2}$

\footnotetext{
${ }^{1}$ Work on this paper was supported by project GOA/12/007, funded by the Research Council of the University of Leuven. Authorship is shared equally. DL presented part of this material at the SLE conference in Split and at a workshop in Leuven. We thank members of the audience for very useful comments on these and other occasions, especially Kristin Davidse, Hendrik De Smet, Nikolaus Himmelmann, Bill McGregor, Peter Petré and Freek Van de Velde. We thank Lesley Stirling and Brett Baker for making available a copy of Stirling \& Baker (2007), Clair Hill, Doug Marmion, Bill McGregor, Erich Round, Adam Saulwick and Stef Spronck for sharing information about their languages of expertise, and Harald Hammarström for help with hard-to-find sources. We are grateful to two reviewers and the editors of Studies in Language for very useful comments on a previous draft, which improved our analysis of the data and the general shape of the argument.

${ }^{2}$ Examples are glossed according to the Leipzig Glossing Rules, which can be consulted at http://www.eva.mpg.de/lingua/resources/glossing-rules.php. Abbreviations not found in the Leipzig Glossing Rules are AUG augmented, CARD cardinal, CONT contemporaneous action, DEF definite, IM immediacy, INCH inchoative, INTENT intentive relator, INTERJ interjection, MIN minimal, PUNC punctual, MOD modal, REAL realis, REP repeat, SEM semblative, UNM unmarked inflection, UNSP unspecified tense, VE vegetation gender.
} 
'The men didn't become aggressive towards the white man.'

(2) Bininj Gun-wok (Evans 2003a: 247)

na-yuhyunggi bedda werrk barri-bukka-ng

I-first.people 3AUG first 3AUG/3.PST-show-PST.PRF

'The first people taught people how to paint first.'

We examine adnominal personal pronouns in a sample of 75 Australian languages, 50 representing the various branches of the Pama-Nyungan family that covers the largest part of the continent, and 25 representing the different non-Pama-Nyungan families found in the continent's northwest. On the basis of these data, we develop two arguments. First, we argue that in all of the structures with adnominal pronouns, the pronoun has a determiner-like function similar to demonstratives or specialized articles, showing both the functional properties and some of the behaviour of more typical determiner categories. Secondly, we show that this phenomenon is relatively widespread in Australia, occurring in about half of the languages examined here, with some clear areal clusters. From a typological perspective, these data present interesting evidence for a somewhat under-studied pathway to nominal determination, in addition to better-studied pathways involving demonstratives (e.g. Himmelmann 1997), numerals (e.g. Himmelmann 2001) or adjectives (e.g. Davidse et al. 2008, Van de Velde 2010). Given that the precise syntactic status of nominal expressions remains uncertain in many Australian languages (see, for instance, Nordlinger 2014), we focus on identifying determining functions rather than determiner status in the classic syntactic sense. In some languages, the pronoun is tightly integrated into a well-defined noun phrase structure, as in the two NPs in the Mparntwe Arrernte structure in (1), and can easily 
also be regarded as filling a determiner slot within the $\mathrm{NP}^{3}$. In others, by contrast, the nature of the syntactic relation between the pronoun and the nominal is less clear (see also Stirling \& Baker 2007), as in the Bininj Gun-wok structure in (2), and the pronoun can only be analysed as a determiner in a functional sense.

Adnominal pronouns have received some attention in earlier work, both in the typological literature on determiners and in the Australianist literature. In his typological study of determining elements, for instance, Himmelmann (1997: 215-219) discusses the Arrernte structures in (1) as one example of how personal pronouns can be a historical source for determiners, in addition to better-documented source categories like demonstratives or possessive pronouns. Similarly, Lyons' (1999) study of definiteness identifies a category of what he calls 'personal determiners', i.e. personal pronouns functioning as determiners (Lyons 1999: 141-145). In the Australianist literature, some grammars explicitly situate adnominal pronouns in the functional domain of 'determination' or label them as 'determiners' (see further in sections 3.2 and 3.3 below), a terminological choice that often reflects a semantic analysis in terms of definiteness effects, or evidence for incipient grammaticization in the pronouns. Following an early suggestion by Hale (1973) for Warlpiri, there are also some more general studies in the Australianist literature: Blake (2001), Stirling \& Baker (2007) and Stirling (2008) all examine adnominal pronouns in a range of Australian languages. Using data from Pitta-Pitta and Kalkatungu, Blake (2001) argues for a general determiner analysis of adnominal pronouns, going so far as to advocate an analysis that takes the determiner as the syntactic head of the construction. Stirling \& Baker (2007) and Stirling (2008) study adnominal pronouns in Kala Lagaw Ya, with comparative evidence from other types of determining categories in other Australian languages, like demonstratives and noun class

\footnotetext{
${ }^{3}$ Whether the form can be regarded as a different part of speech specialized in this slot is an independent question which we will not deal with in this study. As we will show in section 4, however, in some languages there is evidence for incipient grammaticization, which could be interpreted in terms of a change in part of speech status from pronoun to determiner.
} 
markers. They come to a more cautious conclusion, questioning the parallel with classic determiner categories both on syntactic and on discourse-functional grounds.

In very general terms, our analysis in this paper tries to engage with two basic questions that emerge from the existing literature. First, there is some uncertainty about the determining function of these elements, with Blake (2001) clearly arguing in favour of a classic determiner analysis, and Stirling \& Baker (2007) taking a more cautious position. As Himmelmann (1997) has shown, however, questions about the determiner status of pronouns in structures like (1) and (2) above really imply two analytically distinct issues. One is a syntactic question, i.e. whether a language has a clearly defined phrase structure for nominal expressions, and whether the pronoun fills a slot within this structure. The other is a functional question, i.e. whether pronouns that semantically modify nominals, regardless of their syntactic relation to these nominals, have a determining function that is comparable to better-studied determiners like the definite/indefinite article systems found in the Germanic or Romance languages. These two questions are partly independent, in the sense that identifying a determining function for an element does not necessarily imply that it fills a determiner slot in a larger phrasal structure (or forms a separate part of speech, which as mentioned above is yet another question). In this study, we mainly focus on the question of function, showing that there is good semantic and behavioural evidence across our sample for assigning a general determining function to pronouns in structures like (1) and (2). Where relevant, we also touch upon the first question, but we only discuss issues of syntactic constituency where they impinge on the functional question.

The second question that emerges from the literature concerns the occurrence and spread of these constructions in Australian languages. Blake (2001) and Stirling \& Baker (2007) both mention that adnominal pronouns are frequent and typical in Australian languages, but it is not clear how frequent they really are, and where they tend to occur across 
the continent. Our study analyses a fairly large sample of 75 languages (see further in section 2.2 below on the composition of the sample), which gives us a reasonable idea of both frequency and spread. About half of the languages in our sample show some evidence of determining uses for pronouns, with hotbeds in a few areas, most clearly Central Australia and Cape York Peninsula, and possibly also the south-west Kimberley, Arnhem Land and the Gulf of Carpentaria.

The rest of this paper is structured as follows. Section 2 further defines the phenomenon studied here by contrasting it with distinct but related categories and constructions. This section also presents the sample of languages used for this study, and gives a general idea of the frequency of adnominal pronouns in this sample. Section 3 presents arguments for our analysis of a determining function, using evidence from positioning tendencies, semantic and discourse functions, and indications of grammaticization in some languages. Section 4 analyses the areal spread of the constructions, examining the typical properties of determining pronouns in those areas where they are prevalent. Section 5 wraps up the analysis with some conclusions.

\section{$\underline{\text { 2. Definitions and data }}$}

In section 2.1, we define the phenomenon we investigate in some more detail, and in section 2.2 we discuss the data on which our analysis is based. We present the sample of languages we use, and we provide a first assessment of the frequency of the phenomenon across the sample.

\section{$\underline{\text { 2.1. Personal pronouns as modifiers }}$}


This study analyses adnominal pronouns, i.e. personal pronouns used as modifiers for nominals, as exemplified in the structures in (1)-(2) above. We can delineate these structures a bit more precisely in two ways, viz. by contrasting personal pronouns with a number of distinct but closely related categories, like possessive pronouns, demonstratives and person indices (on the verb and elsewhere), and by contrasting their adnominal uses with a number of distinct structures like inalienable possession constructions or resumptive-pronoun constructions.

Our focus on personal pronouns implies that we exclude possessive pronouns and demonstratives, both of which are well-studied as sources for determiners (see Himmelmann 1997). Possessive pronouns are generally easy to distinguish from personal pronouns, because they use a distinct set of roots and/or take a genitive-type case (see Dixon 2002: 315-319 for some more details). Demonstratives, on the other hand, can be more difficult to distinguish from personal pronouns, especially since they are a typical historical source for 3rd person pronouns (see, for instance, Himmelmann 1997: 30, Lyons 1999: 145-148, Bhat 2013). There are a few languages in our sample where the 3rd person slots in pronominal paradigms appear to be filled by demonstratives, but unlike what Blake (2001: 416) argues, these remain a minority. Only for 9 languages out of 75 is it difficult to decide whether 3rd person forms are pronouns or demonstratives (see Table 2 below for a list). Obviously, these languages are left out of the analysis, since they could artificially increase our counts of determining functions for adnominal pronouns (we know that demonstratives are cross-linguistically frequent as a source for determiners). In deciding which languages to leave out, we try to exclude as many potential demonstratives as possible. Specifically, we take the presence of a deictic distance contrast in 3rd person roots as an indication that we may be dealing with demonstratives filling a gap in the paradigm of personal pronouns. Thus, for instance, in Yindjibarndi, 3rd 
person forms in the pronominal paradigm show a contrast between roots for 'near', 'middistant' and 'far' (Wordick 1982: 71-76), as shown in the singular forms in (3) below.

(3) Yindjibarndi (Wordick 1982: 72)

$\begin{array}{lll}\text { 1st person } & & \text { ngayi } \\ \text { 2nd person } & & \text { nyinta } \\ \text { 3rd person } & \text { near } & \text { nhaa } \\ & \text { mid-distant } & \text { wala } \\ & \text { far } & \text { ngunhu / ngunhaa }\end{array}$

In the context of this study, we analyse such forms as potential demonstratives rather than as pronouns, even if they appear to be otherwise well-integrated into the architecture of the pronoun system (e.g. in terms of a kin-related contrast between same-generation and different-generation for dual forms in Yindjibarndi, see further in Wordick 1982: 72). Note that we do not exclude languages where distance contrasts are marked by affixes added to pronominal roots, as is the case in Diyari and Yandruwandha. Both of these languages lack distinct (pronominal and adnominal) demonstrative roots, but they have a set of deictic suffixes which can optionally be added to personal pronouns, when used by themselves or as nominal modifiers (Austin 1981: 60-61, Breen 2004a: 94) ${ }^{4}$. In such cases, we exclude instances with deictic suffixes from our analysis, like (4a) below, but we include those without them, like (4b).

\footnotetext{
${ }^{4}$ Yandruwandha does have a separate set of pronominal demonstratives (Breen 2004a: 59). Pitta-Pitta is another language with deictic suffixes like Diyari and Yandruwandha, but here the suffixes are almost always used, and one of them appears to have grammaticized, serving as the unmarked option when modifying a nominal (Blake 1979: 193-194). Using the same principle of caution as for the other languages, we take this as a grammaticized demonstrative and exclude it from our list of adnominal pronouns in Table 2 below.
} 
(4) Diyari (Austin 1981: 102)

a. pula-ya kinthala malhantyi

3DU.NOM-near dog.NOM bad

'These dogs are bad.'

b. nhani mankarra nhintha pani

3SGF.NOM girl.NOM shame none

'The girl is shameless.'

Within the category of pronouns, we focus only on independent 3rd person forms, i.e. forms that (i) do not refer to the speaker or the interlocutor, and (ii) do not index participants but can establish reference by themselves (beyond adnominal contexts). Speaker- and/or interlocutor-referring forms do occur in combination with nominals in our sample, as shown in the Umpila structure in (5) below. Still, we have chosen not to include these because it is not clear that the pronoun really modifies the nominal in such cases. In a structure with a 3 rd person pronoun, it is obviously the nominal that determines the semantic profile of the referent, and the pronoun contributes very little in the way of descriptive information, apart from number and/or gender in some cases (see below in section 3.2). In structures like (5), by contrast, the pronoun contributes speaker-reference in addition to the semantic profile contributed by the nominal, which makes it difficult to assign a head in semantic terms. From a broader typological perspective, the distinct status of such structures is also reflected in the existence of a whole range of restrictions relating to the person and/or number categories they allow (see Lyons 1999: 141-145 for some examples, and 310-313 for an analysis), which are not found with 3rd person pronouns.

(5) Umpila (Hill ms) 
ngampula ku'unchi inga-na away palu kalmi

1PL.INCL.NOM old.woman speak-NFUT hey INTERJ come

kuuna nhiina-tha-ntu.

neutral.DEM sit-FUT-2PL.NOM

'We old women called out, "Hey you come here and sit down".'

Similarly, many languages in the sample have pronominal indices, in the form of affixes on the verb or clitics with variable hosts, in addition to their independent personal pronouns, as shown in the Jingulu structure in (6) below. Even though in some cases indexing can have a similar effect as a determiner (see Siewierska 2004: 154-157; also Lyons 1999: 207-213), we do not include pronominal indices in our analysis because they do not directly modify the nominal.

(6) Jingulu (Pensalfini 2003: 78)

$$
\begin{array}{lllll}
\text { jama-baja-rni } & \text { yarrulan-darra } & \text { murrkun-bala } & \text { nayu-nga } & \text { durli-wurru-ju. } \\
\text { that.M-PL-ERG } & \text { young.man-PL } & \text { three-PL.ANIM } & \text { woman-F.DAT } & \text { seek-3PL-do }
\end{array}
$$

'Those three young men are looking for women.'

It should be noted here that morphological dependence is only a typical correlate of an indexing function, and that not all morphologically dependent forms have an indexing function, especially when they are the only pronoun forms available in a language. This is the case, for instance, in Ngiyambaa, where 3rd person pronouns are only available as bound forms, encliticized to the first constituent, as shown in (7) below. Such cases are included in our analysis, although obviously the pronoun is by definition not part of the relevant noun phrase in such cases. 
(7) Ngiyambaa (Donaldson 1980: 128)

mirri-gu=na burraay gadhiyi

dog-ERG=3.ABS child. ABS bite.PST

'The dog bit the child.'

In addition to delineating the category of personal pronoun, we also need to further specify the type of pronoun structure we will examine. Our analysis focuses on adnominal uses of pronouns, with the relation between pronoun and nominal defined in functional terms. As already mentioned in the introductory section, we include all structures where a pronoun semantically modifies a nominal, regardless of their syntactic relation to that nominal. Cases like Ngiyambaa in (7) above again illustrate the need to distinguish between the specification of a function for adnominal pronouns in our sample, which we will argue in the following sections is a determining function, and their identification as determiners in a syntactic sense, which as argued above depends on the availability of strictly phrasal structures in the nominal domain. Following Himmelmann (1997), therefore, we will adopt a basic terminological distinction between noun phrases, i.e. phrasal structures that integrate most (or all) elements that semantically modify a noun, and nominal expressions, i.e. a nominal and the elements that modify it, regardless of whether they are integrated into a phrasal structure or not. Henceforth, when we are unsure of the syntactic status of a pronoun relative to a nominal, or when it does not matter for the analysis, we use the more general term nominal expression.

Obviously, our focus on adnominal uses also implies that we should try and exclude any structures where the personal pronoun cannot be analysed as modifying the nominal, like inalienable possession constructions (see, for instance, Blake 1987: 94-98) or NPs followed by a resumptive pronoun (thanks to the reviewers for pointing this out to us). As with the 
question of phrasal integration, the sources do not always allow us to detect such distinctions, but there are some instances where we can. One example is Tiwi, where at first sight personal pronouns can precede or follow nominal expressions (Osborne 1974: 74, Lee 1987: 119, 233 234). However, in a more detailed analysis, Lee (1987: 233-234) explicitly mentions a resumptive function for pronouns following (long) NPs, as in (8) below, and consistently transcribes this with a comma, presumably reflecting prosodic detachment. Such structures are explicitly excluded from our analysis.

(8) Apuyati, naki Anjilim, amintiya muwa mantanga nyirra-naringa, (name) this(M) (name) and $\operatorname{our}(\mathrm{MIN})$ friend(F) her-mother wuta yuwurrara yuwunturrortighi awarra Pukipiyapirayi they two he:fathered:them that(M) (name) 'Apuyati, this one known as Anjilim, and our friend's mother, these two were fathered by Pukipiyapirayi.' (Lee 1987: 233)

To conclude, then, this section leaves us with a definition of adnominal pronouns as structures in which a non-indexing 3rd person pronoun modifies a nominal, as distinct from demonstratives or possessive pronouns modifying nominals, or bound pronouns indexing nominals. We include all instances where such a pronoun semantically modifies a nominal in our analysis, regardless of their syntactic status relative to each other.

\subsection{Sample and spread}

The sample for this study consists of 75 languages, i.e. almost one third of all Australian languages in the more conservative count of about 240 languages at first contact (see Dixon 
2002: 5-7) . Of these 240, about 180 languages belong to the large Pama-Nyungan family that covers the largest part of the continent, and about 60 languages belong to several genetically unrelated families, traditionally negatively identified as non-Pama-Nyungan (about 25 distinct families and isolates, following the classification in Evans 2003b). Our sample consists of 50 Pama-Nyungan languages representing most established subgroups and most regions, and 25 non-Pama-Nyungan languages representing 16 families, i.e. in practical terms most families for which good grammatical descriptions are accessible.

Table 1 below lists the languages in the sample, with their genetic classification and the grammatical description(s) we used. For Pama-Nyungan languages, genetic classification lists both the better-established lower-level subgroups (in the second column) and the higher-level subgroups proposed in Bowern \& Atkinson (2012) (in the third column). For non-PamaNyungan languages, genetic classification is based on Evans (2003b), with one adjustment concerning the status of Enindhilyakwa (now re-classified as a subgroup of Gunwinyguan with Ngandi and Nunggubuyu, following van Egmond 2012).

\section{$\underline{\text { Table } 1 \text { here }}$}

Across this sample, adnominal pronouns are well-represented, with 37 languages in the sample showing evidence for a relevant structure (category 1 in Table 2 below). This evidence either consists of an explicit description in the grammar, or a sufficient number of attestations to suggest that the structure is productive. Furthermore, there are 23 languages in the sample which do not appear to have any relevant structure: either there is no clearly distinct 3rd person pronoun category (category $3 \mathrm{a}$; see section 2.1 above), or the structure is not described

\footnotetext{
${ }^{5}$ There are also more recent counts, like Bowern (2012b), who lists 391 languages but is probably more liberal in distinguishing languages (see comments in Bowern 2011b). On this count, our sample would represent a bit less than one fifth of all Australian languages.
} 
or attested at all in the sources, even though we have good-quality descriptions and sufficient data (category $3 b$ ). In between these two, there is a category of 15 languages that remain uncertain, either because a potentially relevant structure is attested only once or twice and the grammar does not give any idea about its frequency, function or syntactic status (category $2 a$ ), or because the structure is not described or attested at all in a grammar that is otherwise relatively limited in scope (category $2 b$ ). Table 2 lists the languages in the different categories, with reference to the descriptions or attestations in the sources.

$\underline{\text { Table } 2 \text { here }}$

In sum, we can say that adnominal pronouns are fairly frequent in the sample, with good evidence in about half of the languages. If we leave out languages without a clearly distinct category of 3rd person pronouns (category $3 \mathrm{a}$ in Table 2 above), this percentage rises to about $56 \%$. There are also some clear areal patterns in the data, which we discuss in more detail in section 4 below. Because different areas show different degrees of grammaticization of determiners, however, we first turn to the evidence for detecting determiner functions in nominal-modifying pronouns.

\section{$\underline{\text { 3. Pronouns as determiners }}$}

This section brings together the evidence found in the sample to assign a determining function to personal pronouns modifying nominals. Following Rijkhoff (2002), we will define determination as a localizing function, which marks the "place in the world of discourse" for the referent of a nominal expression (Rijkhoff 2002: 173). Section 3.1 presents evidence relating to the position of pronouns, and section 3.2 discusses their meaning or discourse 
function. Although a semantic analysis obviously presents the most direct evidence for a determining function, we first discuss the position of adnominal pronouns, because we have good descriptions of positional tendencies across the whole sample, while meaning and function are described explicitly in only part of the sample. Section 3.3. presents more indirect evidence, showing indications of grammaticization of personal pronouns across the sample.

\section{$\underline{\text { 3.1. Position }}$}

A first argument in favour of a determining function is the typical position of personal pronouns when modifying nominals. If they are adjacent to a nominal expression, they typically occur at the edge, i.e. at the outer left or right edge of the nominal expression, and not in between a nominal and another modifier. This corresponds to a general tendency for determining elements to occur at the edge of noun phrases, possibly reflecting the fact that because of their discourse function they have scope over the entire noun phrase (Rijkhoff 2002: ch 10).

The structures in (9)-(11) below illustrate different edge positions found in the sample, either as fixed positions, especially in languages with clear-cut phrasal structures, or as strong tendencies (with the alternative always being the other edge). The most frequent case is for a personal pronoun to occur in initial position, regardless of the ordering of other modifiers relative to the nominal. That is, this pattern is found both in languages that otherwise have modifiers (like numerals or other nominals) following the head nominal, as in the Guugu Yimidhirr structure in (9), and languages that otherwise have modifiers preceding the head nominal, as in the Kayardild structure in (10). If there is variation in the position of the pronoun, the alternative position is always the other edge rather than any position in between 
another modifier and the nominal (though see below for one principled exception). This is illustrated by the Umpila structures in (11).

(9) Guugu Yimidhirr (Haviland 1979: 103)

bula dyiiral gudhiirra-mu-n yarrba gurra-y

3DU.NOM wife two-mu-ERG thus say-PST

'The two wives spoke thus: ...'

(10) Kayardild (Evans 1995: 239)

niya jungarra dangkaa

3SG.NOM big man

'the big man'

(11) Umpila (Hill ms: 20, 30)

a. pa'amu aa pula pa'amu ku'unchi nhiina-na

two ah 3PL.NOM two old.woman sit-NFUT

'Two, ah, the two old ladies sat.'

b. parra / thathimalu pula-thu kalma-na

white.person island.person 3PL.NOM-MOD come-NFUT

'The white people - the islanders should come.'

The less frequent pattern in the data is for the personal pronoun to occur at the right edge of the nominal expression, often in languages where modifiers follow the nominal, as in the Arrernte structure in (1) above. Table 3 below summarizes positional tendencies in the sample. Regardless of which edge they prefer, the tendency towards edge position for 
adnominal pronouns nicely fits in with a determining function, reflecting scope over the entire nominal expression.

$\underline{\text { Table } 3 \text { here }}$

The general link between position and determining function is confirmed if we look at adnominal pronouns in relation to other elements with determining functions, specifically adnominal demonstratives. When they occur on the same side of the nominal head ${ }^{6}$, adnominal pronouns and demonstratives either compete for the edge position, or they cluster at the edge in contrast to non-determining modifiers. Competition can be illustrated with Uradhi, where the initial slot in the noun phrase can either be filled by a demonstrative or by a personal pronoun, but not both (Crowley 1983: 371), as shown in the NP template provided in (12) below. Clustering at the edge can be illustrated with the structures in (13) and (14) below. In the Arrernte structure in (13), demonstrative and pronoun both follow the head nominal and modifying nominal, while in the Umpila structure in (14), pronoun and demonstrative both precede the head nominal, while modifying nominals follow it.

(12) Uradhi (Crowley 1983: 371)

$\left\{\begin{array}{l}\text { demonstrative } \\ \text { pronoun }\end{array}\right\}($ genitive NP) (N) (Adj)

(13) Mparntwe Arrernte (Wilkins 1989: §3.6.1)

artwe kngerre nhenhe re kere aherre tyerre-ke. man big this 3SG.A game kangaroo shoot-PST.COMPL

'This big man shot a kangaroo.'

\footnotetext{
${ }^{6}$ Obviously, there are also languages in the sample where pronoun and demonstrative occur on either side of the head. In such cases, they occupy opposite edge positions.
} 
(14) Umpila (Hill ms: 4)

ngulu nga'al pulthunu mukan nhiina-na

3SG.NOM DEM.DIST boy big sit-NFUT

'That big boy sat.'

Both of these situations can be regarded as evidence for functional relatedness between the two categories. Competition points to complementary distribution in realizing a determining function, while clustering can be regarded as an instance of what is known as 'over-determination' (see Himmelmann 2001, Plank 2003), i.e. the co-occurrence of more than one determining element.

In fact, a closer examination of clustering of the two categories provides a final bit of evidence for our analysis. In contexts of clustering, it is predominantly the demonstrative that is closer to the head than the pronoun, as in (13) and (14) above. However, the opposite is also attested, as shown in the structures in (15)-(17) below, where demonstratives precede a pronoun in initial position. Such examples are an exception to the generalization that pronouns take the outer edge position, but they a principled one, because this aberrant pattern is only possible among determining elements and not with other modifiers. Apart from the demonstratives illustrated in (15)-(17), the only other instance of this pattern in the sample is found in Mawng, where an adnominal pronoun can be preceded by an article-like element (Singer 2006: 37) ${ }^{7}$, as shown in (18) below.

(15) Kala Lagaw Ya (Ford \& Ober 1991: 130)

senaw nuy garkaz ngaybiya minakay kikirilayg

\footnotetext{
${ }^{7}$ This element may be derived from a gender marker and marks information status (Singer 2006: 37). The second occurrence of the article in (18) is what Singer (2006: 49-50) calls a 'linking article', which occurs in between elements in an NP and does not have an information-status value.
} 
that 3SG boy.ABS 1sg.LOC more sick.PRED

'That boy is more sick than me.'

(16) Wambaya (Nordlinger 1998: 134)

jawaranya ng-u yidanyi ngaba ng-u yardi

billycan.II.ACC 1SG.A-FUT get THEN 1SG.A-FUT put

yaniya cool drink ninaka nanga jugini-nka.

that.IV.SG.ACC cool.drink this.I.SG.DAT 3SGM.OBL boy.I-DAT

'I'm going to get the billycan and put that cold drink (in it) for this boy.'

(17) Yuwaalaraay (Williams 1980: 112)

gi:r nga:ma ganunga biraligal yalu wungalay

PARTICLE the(that) 3PL.S/O child.PL.ABS REP swim-PROG-FUT

'The children will go swimming again. '

(18) Mawng (Singer 2006: 37)

malany ma-warlkanyi-ny-pi mata manat-apa mata warral.

then 3VE-fall-PST.PUNC-TWDS VE 3VE-EMPH1 VE large.paperbark.tree

'Then it fell down, that Warral tree.'

Apparent exceptions like (15)-(18) actually support the case for a determiner analysis, since they show that the only elements that can occur outside the personal pronoun themselves have determining functions. While we are not in a position to explain the relative order of pronouns and other elements in such cases, the clustering of several determining elements in itself is not unsurprising at all from a typological perspective, where as mentioned above it has been described as 'over-determination' (see Himmelmann 2001, Plank 2003).

In sum, we can say that the edge position of personal pronouns is consistent with a determining function, and conforms to the typological generalization that determining 
elements like demonstratives or articles tend to occur in the outer layer of nominal expressions, reflecting scope over the whole expression (Rijkhoff 2002: ch 10, Himmelmann 2001). This argument is further strengthened by the fact that adnominal pronouns often have similar ordering tendencies to demonstratives, sometimes in contrast to ordering tendencies for other modifiers.

\subsection{Function}

While positional tendencies are relatively easy to examine across the sample, it is more difficult to analyse the meaning or function of adnominal pronouns in a consistent way. Not all grammatical sources discuss the meaning or function of the relevant constructions, and if they do so, the descriptions are not always very detailed. Those cases for which we do have information, however, provide further evidence for a determining function.

For the 37 languages in our sample that allow personal pronouns as modifiers, we have 17 grammatical descriptions that provide some more information about their meaning and function. Eleven descriptions out of these 17 analyse the pronouns as markers of definiteness, sometimes in combination with specificity, either using the term definiteness directly or describing its functional basis in terms of assumed identifiability of the referent. Thus, for instance, Austin (1981: 98) argues for Diyari structures like (4b) above:

"Noun phrases in Diyari which contain a pronoun [...] are interpreted as definite, that is, the speaker assumes the hearer can uniquely identify the intended referent(s) of the NP [...]. Third person pronouns without deictic or post-inflectional suffixes can be translated into English as 'the' when preceding other NP constituents." 
Similarly, Wilkins (1989: §3.7.3) describes Arrernte structures like (1) above as "indicat[ing] that the referent of the phrase is a specific entity (or group of entities) which the speaker assumes the addressee can identify from the speech context," and Glasgow (1994: 22) argues for Burarra structures like (19) below that "[t]hird person pronouns are placed at the beginning of NPs (including proper names) as markers of definite reference or when referring to particular individuals."

(19) Burarra (Glasgow 1994: 22)

ni- pa ana-mutika jiny-jortkurrchi-nga Ronnie Smiler an=nika

3MIN-CARD LOC/INSTR-car 3MIN.jin-jump-REAL <name> 3MIN.an=3MIN.POSS

lika ni-pa Ronnie burr-ga-nyja rrawa.

then 3MIN-CARD <name> 3MIN/3AUG-take-REAL home

'She jumped in Ronnie Smiler's car, then Ronnie took them home.'

As is clear from the quotations above, definiteness is often combined with specificity in the available analyses, but a few grammars only identify a function of specificity. Thus, for instance, Gaby (2006: 287-288) argues for Kuuk Thaayorre that "the presence of a pronoun makes a coreferential ${ }^{8} \mathrm{NP}$ specific [...] but not definite" and gives the example in (20) below.

(20) Kuuk Thaayorre (Gaby 2006: 287-288)

kanangkarr pul pam ngumpurr-kak pul, may-i yat

long.ago 3DU.NOM man old.lady-COM 3DU.NOM VEG-DAT go.PST.PFV

'Once upon a time an old man and his wife went looking for food.'

\footnotetext{
${ }^{8}$ Pronouns with determining functions are analysed as separate phrases in apposition to NPs in Kuuk Thaayorre, because they have their own case marking and need not be adjacent to the coreferential NP (Gaby 2006: 87, 291).
} 
Finally, there are also a few descriptions that refer to aspects of discourse structure in their analysis of pronouns modifying nominals. Haviland (1979: 156) argues that "adjoined pronouns and explicit demonstratives" in Guugu Yimidhirr are used "to keep topics straight over a sequence of sentences," and Stirling (2008: 198) argues that structures with modifying pronouns in Kala Lagaw Ya may also relate to narrative structure, in that they "tend to occur towards the beginnings of these [peak story, DL \& JCV] episodes, for primary reintroduction of major characters."

Analyses in terms of definiteness and/or specificity can be directly related to a determining function, since these features have traditionally been associated with different types of determiners (see Himmelmann 1997, Lyons 1999). They deal with the coordination of knowledge between speaker and interlocutor, and therefore serve to locate nominals in the discourse world. Analyses in terms of larger discourse structures like Haviland's (1979) topic analysis and Stirling's (2008) episodic analysis are perhaps less traditionally associated with determiners. However, since they also deal with the way speakers signal aspects of discourse structure to the interlocutor, we see no problems in linking them with classic determiners. In fact, Stirling \& Baker (2007) and Baker (2008) explicitly propose a category of 'topic determiner' to deal with such cases, and to accommodate both the similarities and the differences with 'classic' determiner categories'.

In this sense, we can say that the functional information we have available - which is not complete across the sample - largely confirms a determining function for adnominal pronouns. The only indications we have for any other function than determination in our

\footnotetext{
${ }^{9}$ In Stirling \& Baker's (2008) analysis, the use of adnominal pronouns with proper names is one of the crucial differences between 'topic' determiners and 'classic' determiners, since proper names are inherently definite and thus do not allow a contrast between definite and indefinite. In our data, however, there are quite a few cases of clearly definite/specific adnominal pronouns that can be combined with proper names (see, for instance, (19) above), which suggests that this is not necessarily a distinguishing criterion.
} 
sample concern qualification (in Gooniyandi, see footnote 7 above) and number marking (in Dhuwal). For most languages, number does not appear to be more than an epiphenomenon with adnominal pronouns, but in Dhuwal adnominal pronouns are explicitly linked to the function of number marking, specifically the third person dual and plural pronoun marking dual or plural number for nominals (Morphy 1983: 47-48). Crucially, however, in this case adnominal pronouns behave differently depending on whether they mark determination or number, as shown in (21) below.

(21) Dhuwal (Morphy 1983: 48)

nhina nganya durdakthu-n-a ngunhi-yi dhäruk
sit.UNM 3 SG.ACC learn-UNM-IM that.ABS-ANAPH language.ABS
walal mitjinarri-y walala-y
3PL.NOM missionary-ERG PL-ERG

'The missionaries are now learning this language.'

In Dhuwal, determining pronouns occur NP-initially and have the nominativeaccusative pattern typical of pronouns, while number-marking pronouns immediately follow the nominal head and can take nominal case marking (the 3rd person plural pronoun following the nominal is glossed as 'plural' in (21)). Incidentally, this type of structure further confirms the generalizations from section 3.1, because position is one of the features that distinguishes between determination and number functions. The same applies to Gooniyandi, where adnominal pronouns with a determining function occur in NP-initial position, whereas their counterparts with a qualifying function are in a different position, after the head (McGregor 1990: 267-270). 


\subsection{Incipient grammaticization}

While the position and function of adnominal pronouns provide direct evidence for a determining function, there is also more indirect evidence, which relates to processes of grammaticization affecting adnominal pronouns. As a functional category in the nominal domain, determination is an obvious target for grammaticization processes (as demonstrated, for instance, in Himmelmann 1997; see also Stirling \& Baker 2007). In our sample, this is reflected in the behaviour of adnominal pronouns in some languages, which shows evidence for semantic bleaching, semantic generalization and paradigmatization. We will argue that these properties can be interpreted in terms of grammaticization in most, though perhaps not all, of the languages where they are found.

Apart from the positional tendencies discussed above, many of the adnominal pronouns in the sample are not that different from their 'free' counterparts. They are usually formally identical to free personal pronouns, and they are semantically transparent in the sense that their number or gender value reflects the number or gender of the referent. This is illustrated in the Yawuru structures in (22) below, where a distinction between singular and plural referents is reflected in a distinction between singular (22a) and plural (22b) adnominal pronouns.

(22) Yawuru (Hosokawa 1991: 439)

a. ginyangka dyarn'du

3SG.ABS woman

'that woman'

b. kangadyunu

ngarrungu

3PL.ABS people 
'those people'

Furthermore, adnominal pronouns are usually optional (see also Lyons 1999: 52-53), in the sense that their absence does not imply the absence of the feature they mark, but simply backgrounds this feature (see further in McGregor (2013: 1152, 1156-1160) on this understanding of optionality). Thus, for instance, in Diyari, "noun phrases which do not contain a pronoun [...] can be definite or indefinite depending on the linguistic or extralinguistic context" (Austin 1981: 98), and in Kuuk Thaayorre, "[i]n their absence [of pronouns or demonstratives, DL \& JCV], the NP is simply unspecified for definiteness and specificity" (Gaby 2006: 288). This is illustrated with the Thaayorre structure in (23) below, where nganip 'father' does not use an adnominal pronoun (or any other type of determining element), but is still interpreted as definite and specific.

(23) Kuuk Thaayorre (Gaby 2006: 288)

nganip-i yumpi-rr, nganip ilnen ii father-ERG made-PST.PFV father from.above there 'God made (dogs), God up there'

While this represents the majority pattern, there are a few languages in the sample where pronouns behave differently. Perhaps not coincidentally, these are often also the cases where authors express reservations about the term 'pronoun' in their analysis, and use other terms that are closer to 'determiner'. We still regard these as instances of the phenomenon examined in this paper, because they conform to the basic pattern of polyfunctionality found elsewhere in the sample, i.e. a form that doubles as a personal pronoun and as an adnominal element with a determining function. We will interpret the behavioural differences discussed 
here in terms of grammaticization, although we realize that a more parsimonious approach may be simply to assign different parts of speech, without assuming any historical link or developmental directionality (see further below).

A first point of difference concerns number values. There are languages where the number value of the pronoun does not always reflect the number of referents involved. In Nyulnyul, for instance, there is a form kinyingk which is identical to the third person pronoun, but which the author analyses as a (non-demonstrative) determiner in adnominal uses (McGregor 2011: 158-159). One of the reasons ${ }^{10}$ for this analysis is precisely that the pronominal form by itself has minimal number, but in adnominal position can ${ }^{11}$ also be used with structures that refer to non-minimal referents, as illustrated in the contrast between (24a) and (24b) below.

(24) Nyulnyul (McGregor 2011: 136, 159)

a. angk-ingirr niyar kinyingk wilamay. what-SEM taste DEF food

'What does that food taste like?'

b. kinyingk-kun wamb-uk ni-kard i-ngi-rri-j kinyingk karrambal DEF-ABL 2 man-LOC 3MIN-body 3NOM-PST-AUG-say DEF bird 'Then those birds took on men's form.'

Similarly, Yankunytjatjara has a form palu which could in principle be regarded as a 3rd person singular pronoun, but which Goddard (1985: 58-59) chooses to analyse as a definite marker. It is obviously of pronominal origin, because it has pronoun-specific

\footnotetext{
${ }^{10}$ Another reason is that the adnominal use does not have the suppletive oblique form the free pronoun has, but simply adds the case suffix to the pronominal stem (McGregor 2011: 158).

${ }^{11}$ It is also possible to use the augmented pronoun (see McGregor 2011: 158).
} 
morphology and fills the 'singular' position in the pronoun paradigm, which also has a 3rd person dual and plural (Goddard 1985: 59). One of the reasons why the author chooses to analyse it as a definite marker, however, is that in adnominal use its form is invariable, even when the referent is plural. This is illustrated in (25a) below, where palu is used in a nominal expression that refers to a non-singular referent. Incidentally, this type of example provides further evidence for its grammaticization as a determiner, since it shows how palu can itself be used to modify pronouns, making the pronominal reference specific (as in (25a)) rather than non-specific (as in (25b)).

(25) Yankunytjatjara (Goddard 1985: 59)

a. ngarri-ngu palu-mpa pula-mpa parta-ra

lie-PST DEF-PURP 3DU-PURP wait-SERIAL

'(They) camped, waiting for those two'

b. tjinguru nganarna-nya turaka yungku-ku, tjana,

maybe 1PL-ACC truck give-FUT 3PL

inma-ku muku-rringku-la

dance-PURP like-INCH-SERIAL

'Maybe they'll give us a truck, if they like the dancing.' (a future audience for a dancing tour)

Second, there are also a few languages where adnominal pronouns are not optional in the sense described above, i.e. where the absence of an adnominal pronoun (or any other type of determiner) does mark non-definiteness rather than simply backgrounding the notion of definiteness. In more general terms, this can be analysed as semantic paradigmatization, where the absence of the pronoun no longer has a general pragmatic value (as proposed in 
McGregor's 2013 general analysis of optionality), but a specific semantic value that is tied to the meaning of the adnominal pronoun (in this case its opposite). In our sample, this appears to be the case in Arrernte (Wilkins 1989: §4.2.1) and in Ngiyambaa (Donaldson 1980: 128129). In the Ngiyambaa structures in (26), for instance, the presence or absence of the $3 \mathrm{ABS}$ enclitic is what determines the definiteness value of the object: a definite interpretation in (26a) versus an indefinite one in (26b).

(26) Ngiyambaa (Donaldson 1980: 128)

a. mirri-gu=na burraay gadhiyi dog-ERG=3ABS child.ABS bite.PST

'The dog bit the child.'

b. mirri-gu burraay gadhiyi dog-ERG child.ABS bite.PST

'The dog bit a child/(some) children.'

A final observation that is relevant here is that in some languages adnominal pronouns are semantically generalized, showing no restrictions on the type of referent that is allowed for the relevant nominal expression. While all of the languages in the sample allow animate referents with adnominal pronouns, only a few also allow inanimate ones. It is difficult to get accurate information about this question across the sample: most grammars simply do not provide any examples with inanimate referents, and an apparent restriction to human or animate referents in the data may simply reflect the typical example sentence rather than any inherent restriction. Still, there are a few descriptions that make explicit statements about the exclusion of inanimate referents. Haviland (1979: 104) and Hosokawa (1991: 489) in their grammars of Guugu Yimidhirr and Yawuru comment explicitly on the existence of a 
restriction of adnominal pronouns to animate referents, i.e. they do not allow inanimate referents. There are only a handful of languages in the sample for which inanimate referents are attested, as shown in the structures in (27)-(28) below. One description also explicitly mentions the absence of any restrictions on animacy, in contrast to free pronouns. For Nyulnyul, McGregor (2011: 159) argues that "the determiner kinyingk DEF may occur in an inanimate NP [see (28a) below, DL \& JCV]; the pronoun, by contrast, is never used in reference to inanimates."

(27) a. Kala Lagaw Ya (Comrie 1981: 20, cited in Stirling 2008: 178)

na muy senaki ngapa a moeypunatha-n nan akul.

3SGF.NOM fire.NOM to.there went and burnt-NFUT 3SGF.ACC mussel.ACC

'She, the fire, went there and burnt her, the mussel.'

b. Yandruwandha (Breen 2004b: 188)

ngandjarri warlka-rnangangapala nhunu ngapa marnamininari

rain fall-CONT then 3SG.NOM water brim.full-INCH-UNSP

'When it rains the water fills it to the brim.'

(28) a. Nyulnyul (McGregor 2011: 158)

kinyingk bilabil bardangk-ukun riib arri layib

DEF leaf stick-ABL bad not good

'The leaves of that tree are poisonous.'

b. Mparntwe Arrernte (Wilkins 1989: text 7, line 5)

Elizabeth ne-ke ingke utyene-kerte ante Elizabethe-ke

Elizabeth be-PST.COMPL foot sore-PROP and Elizabeth-DAT

newe-le knge-ke crowbar ulthe-ntye re-nhe

spouse-ERG take-PST.COMPL crowbar press.down-NMLZ(heavy) 3SG-ACC 
'Elizabeth had a sore foot and so her husband carried the heavy crowbar.'

c. Gumbaynggirr (Eades 1979: 345)

baagu ngilina bali-ya muuga-ng

bark.O 3SG.O top-LOC put-PST

'[We] put the bark on top.'

d. Yankunytjatjara (Goddard 1985: 28)

ngayulu kuwarri yana-nyi, palu-nya tjana-nya-kitja

1SG(NOM) now go-PRS DEF-ACC 3PL-ACC-INTENT(NOM)

'I'm going now, for those (things).'

The inanimates attested in the sample fall into two categories. The structures in (27) all involve inanimates that could be regarded as 'motive' elements in the typology of Van Valin \& Wilkins (1996), i.e. inanimates that have their own internal source of energy. These may not be the most representative examples of inanimate referents, as they often behave differently from other inanimates (see, for instance, Fauconnier \& Verstraete 2010, 2014), and could be analysed as personifications in some of the examples in (27). The structures in (28), by contrast, are genuine examples of inanimates, i.e. non-motive elements that could not be analysed as personifications in any sense. It is probably not a coincidence that for these instances, three of the languages quoted also show other features examined here, viz. semantic bleaching (Nyulnyul and Yankunytjatjara) and semantic paradigmatization (Arrernte).

To conclude, then, this section shows that over and above the typical position and function of adnominal pronouns, a few languages in the sample have additional features to distinguish them from their 'free' counterparts. As already mentioned, some authors have interpreted such features in terms of a distinct part of speech status, using terms like determiners, definite markers and the like. Following Himmelmann (1997: 215-219), we 
believe that the same set of features can also be interpreted as indications of the grammaticization of personal pronouns to determiners. One reason is the consistency of the pattern across the sample. All of the 37 languages with adnominal pronouns show the same pattern of polyfunctionality, in which one single form can function both as free pronoun, with a specific referential value, and as a determiner, with a more abstract meaning. This suggests that we are not dealing with accidental homophony, but a more systematic, motivated relation. The phenomena discussed in this section add to this argument because they are often associated with processes of grammaticization, either because they reflect a loss of the referential value associated with personal pronouns (e.g. the number value in Nyulnyul and Yankunytjatjara), or because they reflect the more abstract semantics associated with their determining function (e.g. generalization of reference in Nyulnyul, Arrernte and Yankunytjatjara and semantic paradigmatization in Arrernte and Ngiyambaa). Obviously, we do not have the historical data to substantiate this grammaticization scenario, so we have to be cautious in assigning a diachronic value to all patterns of polyfunctionality. Thus, for instance, McGregor (p.c.) argues that for Nyulnyul kinyingk a grammaticalization scenario is less likely because the form involved is a relatively recent one (see also Stokes \& McGregor 2003: 44-45 $)^{12}$. At least from a typological perspective, however, the consistent pattern of polyfunctionality in about half the languages in our sample, combined with the typical features of semantic bleaching, generalization and paradigmatization in some of them, does seem to fit in with the grammaticization scenario proposed in Himmelmann (1997). Moreover, as will become clear in the following section, the languages discussed in this section are typically also part of a clearly identifiable geographical cluster in our sample, possibly driving the spread of the pattern across distinct but adjacent genetic units.

\footnotetext{
${ }^{12}$ On the other hand, most Nyulnyulan languages seem to have apparent cognates of Nyulnyul kinyingk (Stokes \& McGregor 2003: 42, McGregor 2004: 126-127) for the form that functions as a personal pronoun and a determiner, which may not be incompatible with a grammaticization scenario (see further in section 4 below).
} 


\section{Spread across the sample}

The analysis in the previous sections has shown that adnominal pronouns with determiner functions are not rare at all in Australian languages, found in about half of the languages sampled for this study. If we look at the spread of these structures across the continent, however, their distribution is far from even (see the map in Figure 1 below). There are a few obvious clusters, most clearly in Central Australia and in Cape York Peninsula, and somewhat less clearly in the south-west Kimberley, in Arnhem Land and around the Gulf of Carpentaria. We analyse these in some more detail in this section, looking specifically for areal or genetic patterns in the clusters.

Figure 1 here

The most obvious pattern in this study is a cluster of languages in Central Australia, which consists of all Arandic languages in the sample (Mparntwe Arrernte, Alyawarra), all Karnic languages in the sample ${ }^{13}$ (Diyari, Arabana, Yandruwandhra) and the one Wati language in the sample (Yankunytjatjara). If there is some basis to this cluster, it could be interpreted as an areal grouping, possibly radiating out from the Arandic and Wati subgroups which have grammaticized adnominal pronouns as determiners. There are two observations that, taken together, suggest this interpretation. First, the cluster of languages can definitely not be defined in genetic terms: the three subgroups involved are adjacent, but do not appear

\footnotetext{
${ }^{13}$ We excluded Pitta-Pitta from our list of adnominal pronouns because 3rd person forms have some features of demonstratives (the unmarked form for adnominal pronouns always includes a deictic suffix, see further in footnote 4). Even so, these forms can be used adnominally with determining functions in Pitta-Pitta (Blake 1979: 214), as in the other Karnic languages in the sample.
} 
to be closely related within Pama-Nyungan. In Bowern \& Atkinson's (2012) proposal for higher-level subgrouping of Pama-Nyungan, for instance, Arandic and Karnic both belong to the Central subgroup (in two distinct primary branches), while Wati belongs to the Western subgroup. Secondly, two subgroups, viz. Arandic and Wati, show signs of incipient grammaticization as described in section 3.3. above, while the third does not show these signs. In Arandic, adnominal pronouns in Arrernte allow inanimate reference and show semantic paradigmatization, while in Alyawarra adnominal pronouns as determiners are restricted to 3rd person singular forms (Yallop 1977: 112-113). In Yankunytjatjara, the only Wati language in the sample, adnominal pronouns have invariable number and allow inanimate reference. If we look beyond the sample, other Wati languages like Wangkajunga and Pintupi show similar phenomena (Jones 2011: 109-112, Hansen \& Hansen 1978: 104). In Wangkajunga, for instance, an adnominal 3rd person pronoun marks definiteness, it is found both with singular and plural reference, and it can be used with inanimate referents. If we accept that patterns of grammaticization can drive areal spreads (e.g. Heine \& Kuteva 2005), we could hypothesize that Arandic and Wati languages constitute the centre of this cluster with grammaticizing adnominal pronouns in some languages, radiating out to Karnic, where adnominal pronouns are widespread but do not show signs of grammaticization.

Apart from the Central Australian cluster, a second very clear pattern in the sample is the prevalence of adnominal pronouns throughout Cape York Peninsula. Relevant structures are attested in almost all of the languages of Cape York Peninsula in the sample, traditionally classified as Paman following Hale $(1964,1966)$, including in Kala Lagaw Ya - the Western Torres Strait language, whose subclassification is uncertain (see Bowern \& Atkinson 2012: 833). The three exceptions in the sample are the two closely related languages Yidiny and Djabugay, which have demonstratives filling the 3rd person gap in the paradigm of personal pronouns, and Rimanggudinhma, where we only have one or two examples. Unlike in the 
Central Australian cluster, this cluster has no languages that show clear signs of grammaticization for adnominal pronouns beyond the positional tendencies observed in section 3.1 (and a type of paradigmatization in Uradhi, where adnominal pronouns are in complementary distribution with demonstratives in initial position, see example (12) above). There are also differences in frequency across the region: the structure is infrequent in Umpithamu (Verstraete fieldnotes), for instance, while it is described as frequent or typical for Guugu Yimidhirr (with animate referents, Haviland 1979: 104), and Kugu Nganhcara (Smith \& Johnson 2000: 420-421). The precise function of adnominal pronouns is also less clear than in the Central Australian cluster: definiteness or specificity are mentioned only for two languages (Kuuk Thaayorre and Yir Yoront), and more general discourse patterns are mentioned for the other languages that have descriptions of functions (see above in section 3.2 for some examples). All of this suggests that the cluster is difficult to interpret, beyond the observation that an obvious areal patterning almost coincides with a putative genetic grouping here.

Three other clusters that are a bit less clear in the sample are a cluster of languages associated with the south-west Kimberley, one associated with Arnhem Land, and one associated with the Gulf of Carpentaria. The Kimberley cluster consists of the two Nyulnyulan (non-Pama-Nyungan) languages in the sample (Nyulnyul and Yawuru), the one Bunuban (non-Pama-Nyungan) language in the sample (Gooniyandi), and possibly also the one Worrorran (non-Pama-Nyungan) language in the sample (Worrorra) and the one Marrngu (Pama-Nyungan) language in the sample (Nyangumarta) ${ }^{14}$. One obvious pattern in this cluster concerns Nyulnyulan and Bunuban, where adnominal pronouns with determining functions appear to be widespread. If we look beyond the sample for Nyulnyulan, there are three further Nyulnyulan languages that appear to have adnominal pronouns with determining functions,

\footnotetext{
${ }^{14}$ In fact, this language could possibly also be linked with the Central Australian cluster, as it neighbours Wati languages to its southeast.
} 
viz. Bardi (Bowern 2012a: 288-297), Warrwa (McGregor 1994: 17) and Nyikina (Stokes 1982: 157). The same applies to Bunuban, where Bunuba, the only other Bunuban language, also has adnominal pronouns with determining functions (Rumsey 2000: 73-74). In this sense, Bunuban and Nyulnyulan appear to form the core of the south-west Kimberley cluster ${ }^{15}$, with good evidence for adnominal pronouns across the two groups, and potential evidence for grammaticization in at least one Nyulnyulan language, as discussed in the previous section (although this can be challenged, see also in the previous section for an alternative analysis). The other groups are less uniform if we look beyond the sample. Within Marrngu, there is no evidence for adnominal pronouns in Karajarri (Sands 1989), the only other Marrngu language for which we have access to data. Within Worrorran, there is evidence for adnominal pronouns in Ungarinyin (Rumsey 1982: 134, Spronck p.c.) but not in Gunin (McGregor 1993) or Wunambal (Carr 2000), the only other Worrorran languages for which sufficient material is available (see McGregor \& Rumsey 2009). Moreover, it is difficult to say if adnominal pronouns in these groups can at all be related to the pattern in Nyulnyulan and Bunuban. For Worrorran, our information is limited, both about the southern languages neighbouring Nyulnyulan and about patterns of multilingualism that could have linked them to Nyulnyulan or Bunuban. The best candidate in this regard appears to be Ungarinyin, for which traditional patterns of multilingualism are attested with at least Bunuba (Spronck p.c.). For Nyangumarta, no patterns of multilingualism with Nyulnyulan or Bunuban are mentioned in Sharp's (2004) grammar, or in Hosokawa's (1991) description of the closest Nyulnyulan language Yawuru ${ }^{16}$. Moreover, as already mentioned, Nyangumarta could alternatively also

\footnotetext{
${ }^{15}$ This is why we decided to use the term south-west Kimberley for the cluster, although obviously if Worrorran turns out to be relatable to this cluster, it would have to be renamed the west Kimberley cluster.

${ }^{16}$ Hosokawa (1991) does mention a pattern of multilingualism with Karajarri, which as mentioned earlier does not appear to have adnominal pronouns.
} 
be linked to the Central Australian cluster, given that it neighbours Wati languages to its southeast.

The Arnhem land cluster consists of the two Gunwinyguan (non-Pama-Nyungan) languages in the sample (Bininj Gun-Wok and Rembarrnga), the two Maningrida (non-PamaNyungan) languages in the sample (Burarra and Ndjébbana), as well as two Yolngu (PamaNyungan) languages (Dhuwal and Djinang). Although this area is well-known for its contact effects between Pama-Nyungan and non-Pama-Nyungan languages (e.g. Heath 1978), it is difficult to interpret this cluster as anything more than potentially areally determined: we cannot identify anything like an innovating centre the way we could do this for the Central Australian cluster (although two further Gunwinyguan languages also allow adnominal pronouns infrequently, as described for Nunggubuyu in Heath 1984: 248, and for Dalabon in Cutfield 2013: 54). On the other hand, it may not be a coincidence that a few languages in the same region show another type of determiner-like system, viz. noun class markers functioning as articles (as described in Baker (2008) for Nunggubuyu, Mara and Ngalakan, and in Singer (2006) a bit further away for Mawng). It is hard to tell if this may have had an influence on the adnominal pronouns studied in this paper, but at least Baker (2008) argues that this system is functionally quite different from classic articles, marking topic and focus rather than definiteness and/or specificity.

The Gulf of Carpentaria cluster, finally, consists of the two Tangkic (non-PamaNyungan) languages in the sample (Kayardild and Lardil), the one Garrwan (non-PamaNyungan) language in the sample (Garrwa), and the one Warluwaric (Pama-Nyungan) language in the sample (Yanyuwa). As with the Arnhem Land and the Cape York clusters, it is difficult to detect any clear motivation or internal structure. We cannot identify any innovating centre, and none of the genetic units show clear evidence for relevant structures beyond the sample: there do not appear to be any adnominal pronouns in Yukulta (Tangkic; 
Keen 1983) or Warluwara (Warluwaric, Breen 1971), and while there may be one or two relevant examples in Wakaya (Warluwaric, Breen 1974), their status is uncertain. If we look beyond the cluster, one other thing that may be relevant is its geographic proximity to the Cape York cluster. The two clusters are separated only by a string of languages in the southern Gulf of Carpentaria, viz. the two Tangkic languages Yukulta and Minkin, and the Paman languages Kukatj, Kuthant and Kurtjar. Except for Yukulta (which as just mentioned lacks relevant constructions), however, these are all very scarcely documented, so it is difficult to determine whether they could form a bridge between the two clusters ${ }^{17}$.

To conclude, then, there are five geographical clusters in our data, one or possibly two of which could be analysed as areal groupings radiating out from an innovating centre. Obviously, clusters also imply blanks on the map, but these are more difficult to interpret, since they could also represent a lack of data, especially in the southeastern part of the continent for which the record is least extensive. The record is more reliable for the northern part, however, which means that the absence of relevant constructions in our sample may be significant for the Pilbara region (apart from the north), the Kimberley region (apart from the south-west), the western part of the Top End and the Queensland coast south of Cape York Peninsula. It is probably not a coincidence that this includes the two regions with predominantly non-Pama-Nyungan languages, which typically have person prefixes to the verb that may also take up determining functions (but need not do so, see Evans 2002). Even so, the presence of person prefixes does not necessarily block free adnominal pronouns with determining functions, as shown by the non-Pama-Nyungan languages in the south-west Kimberley and Arnhem land clusters.

\section{Conclusions}

\footnotetext{
${ }^{17}$ At least for Kurtjar there appear to be a few examples of adnominal pronouns (Black \& Gilbert 1986: 8).
} 
In this study, we have explored two questions about the use of adnominal pronouns in Australian languages. First, we have shown that their function can be analysed in terms of determination, as supported by the typical position of adnominal pronouns at the edge of nominal expressions, their meanings of definiteness, specificity or topicality as described in the sources, and indications of incipient grammaticization towards a genuine determiner in a number of languages. Secondly, we have shown that adnominal pronouns with determining functions are widespread in Australian languages, but distributed in a number of geographic clusters, one or possibly two of which can be analysed as areally determined groupings around an innovating centre with incipient grammaticization. From an Australianist perspective, this answers two questions arising from the literature, viz. whether adnominal pronouns are really like determiners, and how widespread their use is. From a broader typological perspective, this study also adds to the literature about the grammaticization of determiners and articles by analysing a somewhat under-described pathway. While there is good literature on source categories like demonstratives (e.g. Himmelmann 1997), numerals (e.g. Himmelmann 2001) or more lexical sources like adjectives (e.g. Davidse et al. 2008, Van de Velde 2010), personal pronouns had only been noted in passing (e.g. Himmelmann 1997, 2001, who was the first to note the relevance of Arrernte and Yankunytjatjara, and Lyons 1999) but - to our knowledge - not surveyed in any detail. Our analysis adds to this literature by identifying a relatively large number of languages that use adnominal pronouns with determining functions, and gives an idea how these elements may have grammaticized towards determiners, although there seem to be very few cases in the sample that can qualify as classic determiners or 'articles'. As already mentioned, in the absence of good historical data, this kind of scenario obviously remains a typologically-based analysis rather than a genuine diachronic one. 
Of course, a survey like the one provided here also leaves quite a few questions unanswered. One relates to the precise function of adnominal pronouns. The functional domain of determination is a broad one, and a typological survey is not the best way to get detailed information about how precisely adnominal elements locate referents in the discourse world, as became clear in section 3.2 above. This can really only be done with corpus studies of individual languages (as provided, for instance, in Himmelmann 1997, Stirling 2008 or Baker 2008). In this perspective, the hypothesis provided by Stirling \& Baker (2007) and Baker (2008) about a basic distinction between classic determiners marking definiteness and/or specificity and 'topic' determiners marking other types of discourse structure is one that should definitely be followed up. In our data, for instance, there are indications that the apparent Cape York cluster of languages has adnominal pronouns of both types. Another question that remains unanswered concerns the precise syntactic relation of adnominal pronouns to nominal expressions and to other types of determining elements in the language. As already mentioned, the syntactic status of nominal expressions remains unclear in many Australian languages, which is also why we were unable to deal with this question systematically in our analysis. Following Himmelmann (1997), however, we could hypothesize that the more grammaticized types of adnominal pronouns are found in languages with more evidence for phrase structure, in other words that the presence of genuine determiners in a language correlates with more classic NP structures. In our sample, this appears to be confirmed for at least Arrernte and Nyulnyul, which (in our interpretation) have the most clearly grammaticized adnominal pronouns in the sample, and also have solid evidence for classic NP structure (see Wilkins 1989: §3.1 and McGregor 2011: 398). A third question that requires more work concerns the nature of the patterns discussed in section 4 . We were able to detect some structure in one or possibly two clusters of languages with adnominal pronouns, with incipient grammaticization that could serve as an innovating centre 
for adjacent genetic units. For the other clusters observed in the sample, it remains to be determined if they really are areally determined clusters, and what it is that motivates the clustering. Conversely, the absence of adnominal pronouns on large parts of the map also raises questions, specifically if there are any factors that may block adnominal pronouns (e.g. pronominal indices on the verb and elsewhere), and if the languages involved have any other systems of determination. Finally, from broader typological perspective, the prevalence of adnominal pronouns with determining functions in Australia also raises the question where else in the world this pattern is found. Again, we do not know of any survey studies, but Himmelmann (1997: 215-217, 2001) offers one lead by analysing grammaticized adnominal pronouns in Nama (Khoe-Kwadi), which could be followed up now that more information is available about the languages of that region.

\section{References}

Alpher, Barry. 1973. Son of ergative: The Yir Yoront language of northeast Australia. Ithaca: Cornell University dissertation.

Alpher, Barry. 1991. Yir-Yoront lexicon: Sketch and dictionary of an Australian language. Berlin: Mouton de Gruyter.

Austin, Peter. 1981. A grammar of Diyari, South Australia. Cambridge: Cambridge University Press.

Baker, Brett. 2008. The interpretation of complex nominal expressions in Southeast Arnhem Land languages. In Ilana Mushin \& Brett Baker (eds.), Discourse and grammar in Australian languages, 135-166. Amsterdam: John Benjamins.

Bannister, Corinne. 2004. A longitudinal study of Ngarrindjeri. Sydney: University of Sydney BA Hons thesis. 
Bhat, D. N. S. 2013. Third person pronouns and demonstratives. In Matthew Dryer \& Martin Haspelmath (eds.), World atlas of language structures online. Leipzig: Max Planck Institute for Evolutionary Anthropology. http://wals.info/chapter/43 (25 August, 2014.)

Black, Paul \& Rolly Gilbert. 1986. Kurtjar dictionary. Manuscript.

Blake, Barry. 1979. Pitta-Pitta. In R. M. W. Dixon \& Barry Blake (eds.), Handbook of Australian languages. Volume 1, 182-242. Canberra: Australian National University Press.

Blake, Barry. 1987. Australian Aboriginal grammar. London: Croom Helm.

Blake, Barry (ed.). 1998. Wathawurrung and the Colac language of Southern Victoria. Canberra: Pacific Linguistics.

Blake, Barry. 2001. The noun phrase in Australian languages. In Jane Simpson, David Nash, Peter Austin \& Barry Alpher (eds.), Forty years on: Ken Hale and Australian languages, 415-425. Canberra: Pacific Linguistics.

Blake, Barry. 2003. The Bunganditj (Buwandik) language of the Mount Gambier region. Canberra: Pacific Linguistics.

Blake, Barry, Luise Hercus, Stephen Morey \& Edward Ryan. 2011. The Mathi group of languages. Canberra: Pacific Linguistics.

Blevins, Juliette. 2001. Nhanda: An Aboriginal language of Western Australia. Honolulu: University of Hawai'i Press.

Bolinger, Dwight. 1967. Adjectives in English: attribution and predication. Lingua 18. 1-34. Bowe, Heather \& Stephen Morey. 1999. The Yorta Yorta (Bangerang) language of the Murray Goulburn including Yabula Yabula. Canberra: Pacific Linguistics.

Bowern, Claire. 2011a. Centroid coordinates for Australian languages v2.0. Google Earth .kmz file. http://pantheon.yale.edu/ clb3/. (25 August, 2014.) 
Bowern, Claire. 2011b. How many languages were spoken in Australia?

http://anggarrgoon.wordpress.com/2011/12/23/how-many-languages-were-spoken-inaustralia/ (25 August, 2014.)

Bowern, Claire. 2012a. A grammar of Bardi. Berlin: Mouton de Gruyter.

Bowern, Claire. 2012b. Master list of Australian languages v 1.2. http://pamanyungan.sites.yale.edu/master-list-australian-languages-v12 (25 August, 2014.)

Bowern, Claire \& Quentin Atkinson. 2012. Computational phylogenetics and the internal structure of Pama-Nyungan. Language 88. 817-845.

Bradley, John. 1992. Yanyuwa Wuka: Language from Yunyuwa country. Manuscript. http://eprint.uq.edu.au/archive/00000072/01/yanyuwatotal.pdf (25 August, 2014.)

Breen, Gavan. 1971. A description of Warluwara. Melbourne: Monash University MA thesis.

Breen, Gavan. 1974. Wakaya grammar. Manuscript.

Breen, Gavan. 2004a. Innamincka talk: A grammar of the Innamincka dialect of Yandruwandha with notes on other dialects. Canberra: Pacific Linguistics.

Breen, Gavan. 2004b. Innamincka words: Yandruwandha dictionary and stories. Canberra: Pacific Linguistics.

Breen, Gavan \& Barry Blake. 2007. The grammar of Yalarnnga: A language of Western Queensland. Canberra: Pacific Linguistics.

Carr, Thérèse. 2000. Wunambal: A language of the North-West Kimberley region, Western Australia. Armidale: University of New England MA thesis.

Chafe, Wallace. 1976. Givenness, contrastiveness, definiteness, subjects, topics and point of view. In Charles Li (ed.), Subject and topic, 27-55. New York: Academic Press.

Clendon, Mark. 2000. Topics in Worora grammar. Adelaide: University of Adelaide dissertation. 
Clendon, Mark. 2014. Worrorra: A language of the North-West Kimberley coast. Adelaide: University of Adelaide Press.

Comrie, Bernard. 1981. Ergativity and grammatical relations in Kalaw Lagaw Ya (Saibai Dialect). Australian Journal of Linguistics 1. 1-42.

Crowley, Terry. 1983. Uradhi. In R. M. W. Dixon \& Barry Blake (eds.), Handbook of Australian languages. Volume 3, 306-428. Canberra: Australian National University Press.

Cutfield, Sarah. 2013. Demonstratives in Dalabon: A language of southwestern Arnhem Land. Melbourne: Monash University dissertation.

Davidse, Kristin, Tine Breban \& An Van Linden. 2008. Deictification: The development of secondary deictic meanings by adjectives in the English NP. English Language and Linguistics 12. 475-503.

Dench, Alan. 1991. Panyjima. In R. M. W. Dixon \& Barry Blake (eds.), Handbook of Australian languages. Volume 4, 124-243. Oxford: Oxford University Press.

Dench, Alan. 1994. Martuthunira: A language of the Pilbara region of Western Australia. Canberra: Pacific Linguistics.

Dench, Alan. 1998. Yingkarta. München: Lincom Europa.

Dixon, R. M. W. 1977. A grammar of Yidiny. Cambridge: Cambridge University Press.

Dixon, R. M. W. 1991. Words of our country. St. Lucia: University of Queensland Press.

Dixon, R. M. W. 2002. Australian languages: Their nature and development. Cambridge: Cambridge University Press.

Donaldson, Tamsin. 1980. Ngiyambaa: The language of the Wangaaybuwan. Cambridge: Cambridge University Press.

Douglas, Wilfrid. 1976. The Aboriginal languages of the South-West of Australia. 2nd edn. Canberra: Australian Institute of Aboriginal Studies. 
Douglas, Wilfrid. 1981. Watjarri. In R. M. W. Dixon \& Barry Blake (eds.), Handbook of Australian languages. Volume 2, 197-272. Canberra: Australian National University Press.

Eades, Diana. 1979. Gumbaynggirr. In R. M. W. Dixon \& Barry Blake (eds.), Handbook of Australian languages. Volume 1, 244-361. Canberra: Australian National University Press.

Egmond, Marie-Elaine van. 2012. Enindhilyakwa phonology, morphosyntax and genetic position. Sydney: University of Sydney dissertation.

Evans, Nicholas. 1995. A grammar of Kayardild with historical-comparative notes on Tangkic. Berlin: Mouton de Gruyter.

Evans, Nicholas. 2002. The true status of grammatical object affixes: Evidence from Bininj Gun-wok. In Nicholas Evans \& Hans-Jürgen Sasse (eds.), Problems of polysynthesis, 15-50. Berlin: Akademie Verlag.

Evans, Nicholas. 2003a. Bininj Gun-wok: A pan-dialectal grammar of Mayali, Kunwinjku and Kune. Canberra: Pacific Linguistics.

Evans, Nicholas. 2003b. Introduction: Comparative non-Pama-Nyungan and Australian historical linguistics. In Nicholas Evans (ed.), The non-Pama-Nyungan languages of Northern Australia, 3-25. Canberra: Pacific Linguistics.

Fauconnier, Stefanie \& Jean-Christophe Verstraete. 2010. Distinguishing animacy effects for Agents: A case study of Australian languages. Australian Journal of Linguistics 30. 183-207.

Fauconnier, Stefanie \& Jean-Christophe Verstraete. 2014. A and O as each other's mirror image? Problems with markedness reversal. Linguistic Typology 18. 3-49.

Ford, Kevin \& Dana Ober. 1987. Kalaw Kawaw Ya. Darwin: School of Australian Linguistics. 
Ford, Kevin \& Dana Ober. 1991. A sketch of Kalaw Kawaw Ya. In Suzanne Romaine (ed.), Language in Australia, 118-142. Cambridge: Cambridge University Press.

Ford, Lysbeth. 1998. A description of the Emmi language of the Northern Territory of Australia. Canberra: Australian National University dissertation.

Gaby, Alice Rose. 2006. A grammar of Kuuk Thaayorre. Melbourne: University of Melbourne dissertation.

Glasgow, Kathy. 1994. Appendix 2: Parts of Speech (or major word classes) in Burarra Gun-Nartpa. Burarra-Gun-Nartpa dictionary: With English finder list, 893-924.

Darwin: Summer Institute of Linguistics.

Goddard, Cliff. 1985. A grammar of Yankunytjatjara. Alice Springs: Institute for Aboriginal Development.

Godman, Irene. 1993. A sketch grammar of Rimanggudinhma: A language of the Princess Charlotte Bay region of Cape York Peninsula. St Lucia: University of Queensland BA Hons thesis.

Green, Ian. 1989. Marrithiyel: A language of the Daly River region of Australia's Northern Territory. Canberra: Australian National University dissertation.

Green, Rebecca. 1987. A sketch grammar of Burarra. Canberra: Australian National University BA Hons thesis.

Hale, Ken. 1964. Classification of Northern Paman languages, Cape York Peninsula, Australia: A research report. Oceanic Linguistics 3. 248-265.

Hale, Ken. 1966. Languages of the world: Indo-Pacific fascicle six: Appendix to XXIX: The Paman group of the Pama-Nyungan phylic family. Anthropological Linguistics 8. 162 197.

Hale, Ken. 1973. Person marking in Walbiri. In Stephen Anderson \& Paul Kiparsky (eds.), A Festschrift for Morris Halle, 308-344. New York: Holt, Rinehart \& Winston. 
Hale, Ken. 1995. An elementary Warlpiri dictionary. Revised edn. Alice Springs: IAD Press.

Hale, Ken, Mary Laughren \& Jane Simpson. 1995. Warlpiri. In Joachim Jacobs, Arnim von Stechow, Wolfgang Sternefeld \& Theo Vennemann (eds.), Syntax. An International Handbook of Contemporary Research, vol. 2, 1430-1451. Berlin: Mouton de Gruyter. Hamilton, Philip. 1996. Oykangand sketch grammar. Manuscript.

Hansen, Kenneth \& Lesley Hansen. 1978. The core of Pintupi grammar. Darwin: Summer Institute of Linguistics.

Harvey, Mark. 2001. A grammar of Limilngan: A language of the Mary River region, Northern Territory, Australia. Canberra: Pacific Linguistics.

Harvey, Mark. 2002. A grammar of Gaagudju. Berlin: Mouton de Gruyter.

Haviland, John. 1979. Guugu Yimidhirr. In Robert M. W. Dixon \& Barry Blake (eds.), Handbook of Australian languages. Volume 1, 27-180. Canberra: Australian National University.

Heath, Jeffrey. 1978. Ngandi grammar, texts and dictionary. Canberra: Australian Institute of Aboriginal Studies.

Heath, Jeffrey. 1980. Basic materials in Ritharngu: grammar, texts and dictionary. Canberra: Pacific Linguistics.

Heath, Jeffrey. 1981. Basic materials in Mara: grammar, texts and dictionary. Canberra: Pacific Linguistics.

Heath, Jeffrey. 1984. Functional grammar of Nunggubuyu. Canberra: Australian Institute of Aboriginal Studies.

Heine, Bernd \& Tania Kuteva. 2005. Language contact and grammatical change. Cambridge: Cambridge University Press.

Hercus, Luise. 1982. The Baagandji language. Canberra: Pacific Linguistics. 
Hercus, Luise. 1994. A grammar of the Arabana-Wangkangurru language, Lake Eyre Basin, South Australia. Canberra: Pacific Linguistics.

Hill, Clair. ms. The noun phrase in Umpila. Manuscript.

Himmelmann, Nikolaus. 1997. Deiktikon, Artikel, Nominalphrase: Zur Emergenz syntaktischer Struktur. Tübingen: Niemeyer.

Himmelmann, Nikolaus. 2001. Articles. In Martin Haspelmath (ed.), Language typology and language universals: An international handbook, 831-841. Berlin: Mouton de Gruyter.

Hosokawa, Komei. 1991. The Yawuru language of West Kimberley: a meaning-based description. Canberra: Australian National University dissertation.

Hudson, Joyce. 1978. The core of Walmatjari grammar. Canberra: Australian Institute of Aboriginal Studies.

Jones, Barbara. 2011. A grammar of Wangkajunga: A language of the Great Sandy Desert of North Western Australia. Canberra: Pacific Linguistics.

Keen, Sandra. 1983. Yukulta. In R. M. W. Dixon \& Barry Blake (eds.), Handbook of Australian languages. Volume 3, 190-305. Canberra: Australian National University Press.

Kirton, Jean. 1971. Papers in Australian Linguistics No. 5. Canberra: Pacific Linguistics.

Kirton, Jean \& Bella Charlie. 1996. Further aspects of the grammar of Yanyuwa, Northern Australia. Canberra: Pacific Linguistics.

Kite, Suzanne \& Stephen Wurm. 2004. The Duungidjawu language of Southeast Queensland: grammar, texts and vocabulary. Canberra: Pacific Linguistics.

Klokeid, Terry. 1976. Topics in Lardil grammar. Cambridge: MT dissertation.

Lee, Jennifer. 1987. Tiwi today: A study of language change in a contact situation. Canberra: Pacific Linguistics.

Lyons, Christopher. 1999. Definiteness. Cambridge: Cambridge University Press. 
Marmion, Douglas. 1996. A description of the morphology of Wajarri. Armidale: University of New England BA Hons thesis.

McGregor, William. 1990. A functional grammar of Gooniyandi. Amsterdam: John Benjamins.

McGregor, William. 1993. Gunin/Kwini. München: Lincom.

McGregor, William. 1994. Warrwa. München: Lincom.

McGregor, William. 2004. The languages of the Kimberley, Western Australia. London: RoutledgeCurzon.

McGregor, William. 2011. The Nyulnyul language of Dampier Land, Western Australia. 2 vols. Canberra: Pacific Linguistics.

McGregor, William. 2013. Optionality in grammar and language use. Linguistics 51. 11471204.

McGregor, William \& Alan Rumsey. 2009. Worrorran revisited. Canberra: Pacific Linguistics.

McKay, Graham. 1975. Rembarnga: A language of central Arnhem Land. Canberra: Australian National University dissertation.

McKay, Graham. 2000. Ndjébbana. In R. M. W. Dixon \& Barry J. Blake (eds.), Handbook of Australian Languages. Volume 5, 155-356. Oxford: Oxford University Press.

Meakins, Felicity \& Rachel Nordlinger. 2014. A grammar of Bilinarra: An Australian Aboriginal language of the Northern Territory. Berlin: Mouton de Gruyter.

Merlan, Francesca. 1994. A grammar of Wardaman: A language of the Northern Territory of Australia. Berlin: Mouton de Gruyter.

Morphy, Frances. 1983. Djapu, a Yolngu dialect. In R. M. W. Dixon \& Barry Blake (eds.), Handbook of Australian languages. Volume 3, 1-188. Canberra: Australian National University Press. 
Mushin, Ilana. 2012. A grammar of (Western) Garrwa. Berlin: Mouton de Gruyter.

Nash, David. 1980. Topics in the Warlpiri grammar. Cambridge: MT dissertation,.

Nordlinger, Rachel. 1998. A grammar of Wambaya, Northern Territory (Australia). Canberra: Pacific Linguistics.

Nordlinger, Rachel. 2014. Constituency and grammatical relations. In Harold Koch \& Rachel Nordlinger (eds.), The languages and linguistics of Australia: A comprehensive guide, 215-262. Berlin: Mouton de Gruyter.

Osborne, Charles. 1974. The Tiwi language. Canberra: AIAS.

Patz, Elisabeth. 1991. Djabugay. In R. M. W. Dixon \& Barry Blake (eds.), Handbook of Australian languages. Volume 4, 244-347. Oxford: Oxford University Press.

Patz, Elisabeth. 2002. A grammar of the Kuku Yalanji language of North Queensland. Canberra: Pacific Linguistics.

Pensalfini, Robert. 2003. A grammar of Jingulu: An Aboriginal language of the Northern Territory. Canberra: Pacific Linguistics.

Plank, Frans. 2003. Double articulation. In Frans Plank (ed.), Noun phrase structure in the languages of Europe, 337-396. Berlin: Mouton de Gruyter.

Reid, Nick. 1990. Ngan'gityemerri: A language of the Daly River region, Northern Territory of Australia. Canberra: Australian National University dissertation.

Rijkhoff, Jan. 2002. The noun phrase. Oxford: Oxford University Press.

Round, Erich. 2013. Kayardild morphology and syntax. Oxford: Oxford University Press.

Rumsey, Alan. 1982. An intra-sentence grammar of Ungarinjin, North-Western Australia. Canberra: Pacific Linguistics.

Rumsey, Alan. 2000. Bunuba. In R. Dixon \& B. Blake (eds.), Handbook of Australian languages. Volume 5, 34-152. Oxford: Oxford University Press. 
Sands, 1989. A grammar of Garadjari, Western Australia. Canberra: Australian National University BA thesis.

Saulwick, Adam. 2003. Aspects of the verb in Rembarrnga: A polysynthetic language of northern Australia. Grammatical description, texts and dictionary. Melbourne: University of Melbourne dissertation.

Schebeck, Bernard. 1974. Texts on the social system of the Atnyamathanha people with grammatical notes. Canberra: Pacific Linguistics.

Schultze-Berndt, Eva. 2000. Simple and complex verbs in Jaminjung: A study of event categorisation in an Australian language. Nijmegen: Katholieke Universiteit Nijmegen dissertation.

Sharp, Janet. 2004. Nyangumarta: A language of the Pilbara region of Western Australia. Canberra: Pacific Linguistics.

Sharpe, Margaret. 1972. Alawa phonology and grammar. Canberra: Australian Institute of Aboriginal Studies.

Siewierska, Anna. 2004. Person. Cambridge: Cambridge University Press.

Simpson, Jane. 1983. Aspects of Warlpiri morphology and syntax. Cambridge: MIT dissertation.

Singer, Ruth. 2006. Agreement in Mawng: Productive and lexicalised uses of agreement in an Australian language. Melbourne: University of Melbourne dissertation.

Smith, Ian \& Steve Johnson. 2000. Kugu Nganhcara. In R. M. W. Dixon \& Barry J. Blake (eds.), Handbook of Australian Languages. Volume 5, 357-507. Oxford: Oxford University Press.

Sommer, Bruce. 1970. Kunjen syntax: A generative view. Honolulu: University of Hawaii dissertation. 
Sommer, Bruce. 2006. Speaking Kunjen: An ethnography of Oykangand kinship and communication. Canberra: Pacific Linguistics.

Stirling, Lesley. 2008. "Double reference" in Kala Lagaw Ya narratives. In Ilana Mushin \& Brett Baker (eds.), Discourse and grammar in Australian languages, 167-202. Amsterdam: John Benjamins.

Stirling, Lesley \& Brett Baker. 2007. Pronominal apposition and the status of "determiner" in Australian languages. Presentation, Australian Linguistic Society Annual Conference, Adelaide.

Stokes, Bronwyn. 1982. A description of Nyigina: A language of the West Kimberley, Western Australia. Canberra: Australian National University dissertation.

Stokes, Bronwyn \& William McGregor. 2003. Classification and subclassification of the Nyulnyulan languages. In Nick Evans (ed.), The non-Pama-Nyungan languages of Northern Australia, 29-74. Canberra: Pacific Linguistics.

Swartz, Stephen. 1982. Syntactic structure of Warlpiri clauses. In Stephen Swartz (ed.), Papers in Warlpiri grammar: In memory of Lothar Jagst, 69-127. Darwin: Summer Institute of Linguistics.

Terrill, Angela. 2002. Dharumbal: The language of Rockhampton, Australia. Canberra: Pacific Linguistics.

Thompson, David. 1988. Lockhart River “Sand Beach” language: An outline of Kuuku Ya'U and Umpila. Darwin: Summer Institute of Linguistics.

Tsunoda, Tasaku. 1981. The Djaru language of Kimberley, Western Australia. Canberra: Pacific Linguistics.

Tsunoda, Tasaku. 2011. A grammar of Warrongo. Berlin: Mouton de Gruyter.

Van de Velde, Freek. 2010. The emergence of the determiner in the Dutch NP. Linguistics 48. 263-299. 
Van Valin, Robert \& David Wilkins. 1996. The case for "Effector": Case roles, agents and agency revisited. In Masayoshi Shibitani \& Sandra A. Thompson (eds.), Grammatical constructions: Their form and meaning, 289-322. Oxford: Oxford University Press.

Verstraete, Jean-Christophe. ms. The noun phrase in Umpithamu. Manuscript.

Waters, Bruce. 1989. Djinang and Djinba: A grammatical and historical perspective. Canberra: Pacific Linguistics.

Wilkins, David. 1989. Mparntwe Arrernte (Aranda): Studies in the structure and semantics of Grammar. Canberra: Australian National University dissertation.

Wilkinson, Melanie. 1991. Djambarrpuyngu: A Yolngu variety of Northern Australia. Sydney: University of Sydney dissertation.

Williams, Corinne. 1980. A grammar of Yuwaalaraay. Canberra: Pacific Linguistics.

Wordick, Frank. 1982. The Yindjibarndi language. Canberra: Pacific Linguistics.

Yallop, Colin. 1975. The Narinjari language 1864-1964. In A. P. Elkin (ed.), Narinjari: An outline of the language studied by George Taplin, with Taplin's notes and comparative table. Sydney: University of Sydney.

Yallop, Colin. 1977. Alyawarra: An Aboriginal language of Central Australia. Canberra: Australian Institute of Aboriginal Studies. 


\begin{tabular}{|c|c|c|c|}
\hline Language name & \multicolumn{2}{|l|}{ Genetic status } & References \\
\hline & \multicolumn{3}{|c|}{ Pama-Nyungan (PN) } \\
\hline Kala Lagaw Ya & (unclear) & Northern PN & $\begin{array}{l}\text { Ford \& Ober (1987, 1991), } \\
\text { Stirling (2008) }\end{array}$ \\
\hline Uradhi & Northern Paman & Northern PN & Crowley (1983) \\
\hline Umpila/Kuuku Ya’u & Middle Paman & Northern PN & $\begin{array}{l}\text { Hill (ms), Thompson } \\
\text { (1988) }\end{array}$ \\
\hline Kugu Nganhcara & Middle Paman & Northern PN & Smith \& Johnson (2000) \\
\hline Umpithamu & Middle Paman & Northern PN & $\begin{array}{l}\text { Verstraete (ms \& } \\
\text { fieldnotes) }\end{array}$ \\
\hline Rimanggudinhma & $\begin{array}{l}\text { Lamalamic } \\
\text { (Paman) }\end{array}$ & Northern PN & Godman (1993) \\
\hline Kuuk Thaayorre & Southwest Paman & Northern PN & Gaby (2006) \\
\hline Oykangand & Southwest Paman & Northern PN & $\begin{array}{l}\text { Hamilton (1996); Sommer } \\
(1970,2006)\end{array}$ \\
\hline Yir Yoront & Southwest Paman & Northern PN & Alpher $(1973,1991)$ \\
\hline Guugu Yimidhirr & $\begin{array}{l}\text { Yimidhirr- } \\
\text { Yalanji-Yidinic } \\
\text { (Paman) }\end{array}$ & Northern PN & Haviland (1979) \\
\hline Kuku Yalanji & $\begin{array}{l}\text { Yimidhirr- } \\
\text { Yalanji-Yidinic } \\
\text { (Paman) }\end{array}$ & Northern PN & Patz (2002) \\
\hline Yidiny & $\begin{array}{l}\text { Yimidhirr- } \\
\text { Yalanji-Yidinic } \\
\text { (Paman) }\end{array}$ & Northern PN & Dixon $(1977,1991)$ \\
\hline
\end{tabular}




\begin{tabular}{|c|c|c|c|}
\hline Djabugay & $\begin{array}{l}\text { Yimidhirr- } \\
\text { Yalanji-Yidinic } \\
\text { (Paman) }\end{array}$ & Northern PN & Patz (1991) \\
\hline Dharumbal & Maric & Northern PN & Terrill (2002) \\
\hline Warrongo & Maric & Northern PN & Tsunoda (2011) \\
\hline Yalarnnga & Kalkatungic & Northern PN & Breen \& Blake (2007) \\
\hline Duunidjawu & Waka-Kabi & $\begin{array}{l}\text { South- } \\
\text { Eastern PN }\end{array}$ & Kite \& Wurm (2004) \\
\hline Gumbaynggirr & Gumbaynggirr & $\begin{array}{l}\text { South- } \\
\text { Eastern PN }\end{array}$ & Eades (1979) \\
\hline Yuwaalaraay & $\begin{array}{l}\text { Central New } \\
\text { South Wales }\end{array}$ & $\begin{array}{l}\text { South- } \\
\text { Eastern PN }\end{array}$ & Williams (1980) \\
\hline Ngiyambaa & $\begin{array}{l}\text { Central New } \\
\text { South Wales }\end{array}$ & $\begin{array}{l}\text { South- } \\
\text { Eastern PN }\end{array}$ & Donaldson (1980) \\
\hline Wathawurrung & Kulin & $\begin{array}{l}\text { South- } \\
\text { Eastern PN }\end{array}$ & Blake (1998) \\
\hline Mathi group & Kulin & $\begin{array}{l}\text { South- } \\
\text { Eastern PN }\end{array}$ & Blake et al. (2011) \\
\hline $\begin{array}{l}\text { Bunganditj/ } \\
\text { Buwandik }\end{array}$ & $\begin{array}{l}\text { Bunganditj/ } \\
\text { Buwandik }\end{array}$ & $\begin{array}{l}\text { South- } \\
\text { Eastern PN }\end{array}$ & Blake (2003) \\
\hline Yorta Yorta & Eastern Victoria & $\begin{array}{l}\text { South- } \\
\text { Eastern PN }\end{array}$ & Bowe \& Morey (1999) \\
\hline Ngarrindjerri & Lower Murray & $\begin{array}{l}\text { South- } \\
\text { Eastern PN }\end{array}$ & $\begin{array}{l}\text { Bannister (2004), Yallop } \\
\text { (1975) }\end{array}$ \\
\hline Arabana/ & Karnic & Central PN & Hercus (1994) \\
\hline
\end{tabular}




\begin{tabular}{|c|c|c|c|}
\hline Wangkangurru & & & \\
\hline Pitta-Pitta & Karnic & Central PN & Blake (1979) \\
\hline Diyari & Karnic & Central PN & Austin (1981) \\
\hline $\begin{array}{l}\text { Yandruwandha } \\
\text { (Innamincka) }\end{array}$ & Karnic & Central PN & Breen $(2004 a, b)$ \\
\hline Paakantyi & Paakantyi & Central PN & Hercus (1982) \\
\hline Atynyamathanha & Thura-Yura & Central PN & Schebeck (1974) \\
\hline Alyawarra & Arandic & Central PN & Yallop (1977) \\
\hline $\begin{array}{l}\text { Arrernte } \\
\text { (Mparntwe) }\end{array}$ & Arandic & Central PN & Wilkins (1989) \\
\hline Warlpiri & Ngumpin-Yapa & Western PN & $\begin{array}{l}\text { Hale (1995), Hale et al. } \\
(1995), \text { Nash (1980), } \\
\text { Simpson (1983), Swartz } \\
\text { (1982) }\end{array}$ \\
\hline Bilinarra & Ngumpin-Yapa & Western PN & $\begin{array}{l}\text { Meakins \& Nordlinger } \\
\text { (2014) }\end{array}$ \\
\hline Jaru & Ngumpin-Yapa & Western PN & Tsunoda (1981) \\
\hline Walmajarri & Ngumpin-Yapa & Western PN & Hudson (1978) \\
\hline Nyangumarta & Marrngu & Western PN & Sharp (2004) \\
\hline Yankunytjatjara & Wati & Western PN & Goddard (1985) \\
\hline Martuthunira & Ngayarta & Western PN & Dench (1994) \\
\hline Yindjibarndi & Ngayarta & Western PN & Wordick (1982) \\
\hline Panyjima & Ngayarta & Western PN & Dench (1991) \\
\hline Wajarri & Kartu & Western PN & $\begin{array}{l}\text { Douglas (1981), Marmion } \\
\text { (1996) }\end{array}$ \\
\hline
\end{tabular}




\begin{tabular}{|c|c|c|c|}
\hline Yingkarta & Kartu & Western PN & Dench (1998) \\
\hline Nhanda & Nhanda & Western PN & Blevins (2001) \\
\hline Nyungar & Nyungar & Western PN & Douglas (1976) \\
\hline Ritharngu & Yolngu & Western PN & Heath (1980) \\
\hline $\begin{array}{l}\text { Dhuwal } \\
\text { (Djapu/Djamparrpuy } \\
\text { ngu) }\end{array}$ & Yolngu & Western PN & $\begin{array}{l}\text { Morphy (1983), } \\
\text { Wilkinson (1991) }\end{array}$ \\
\hline Djinang/Djinba & Yolngu & Western PN & Waters (1989) \\
\hline Yanyuwa & Warluwaric & Western PN & $\begin{array}{l}\text { Kirton (1971), Kirton \& } \\
\text { Charlie (1996), Bradley } \\
\text { (1992) }\end{array}$ \\
\hline \multicolumn{4}{|c|}{ non-Pama-Nyungan } \\
\hline Kayardild & Tangkic & & $\begin{array}{l}\text { Evans (1995), Round } \\
\text { (2013) }\end{array}$ \\
\hline Lardil & Tangkic & & Klokeid (1976) \\
\hline Garrwa & Garrwan & & Mushin (2012) \\
\hline Mara & Maran & & Heath (1981) \\
\hline Alawa & Maran & & Sharpe (1972) \\
\hline Wambaya & Mindi & & Nordlinger (1998) \\
\hline Jingulu & Mindi & & Pensalfini (2003) \\
\hline Jaminjung & Mindi & & Schultze-Berndt (2000) \\
\hline Emmi & Western Daly & & Ford (1998) \\
\hline Marrithiyel & Western Daly & & Green (1989) \\
\hline $\begin{array}{l}\text { Ngan'gityemerri/ } \\
\text { Ngan'gikurunggurr }\end{array}$ & Southern Daly & & Reid (1990) \\
\hline
\end{tabular}




\begin{tabular}{|c|c|c|}
\hline Wardaman & Wardaman/ Wagiman & Merlan (1994) \\
\hline Gaagudju & Gaagudju & Harvey (2002) \\
\hline Limilngan & Limilngan & Harvey (2001) \\
\hline Tiwi & Tiwi & $\begin{array}{l}\text { Osborne (1974), Lee } \\
\text { (1987) }\end{array}$ \\
\hline Rembarrnga & Gunwinyguan & $\begin{array}{l}\text { McKay (1975), Saulwick } \\
(2003)\end{array}$ \\
\hline Bininj Gun-wok & Gunwinyguan & Evans (2003a) \\
\hline Enindhilyakwa & Gunwinyguan & van Egmond (2012) \\
\hline Burarra & Maningrida & $\begin{array}{l}\text { Green (1987), Glasgow } \\
\text { (1994) }\end{array}$ \\
\hline Ndjébbana & Maningrida & McKay (2000) \\
\hline Mawng & Iwaidjan & Singer (2006) \\
\hline Gooniyandi & Bunuban & McGregor (1990) \\
\hline Nyulnyul & Nyulnyulan & McGregor (2011) \\
\hline Yawuru & Nyulnyulan & Hosokawa (1991) \\
\hline Worrorra & Worrorran & Clendon $(2000,2014)$ \\
\hline
\end{tabular}

Table 1: The sample 


\begin{tabular}{|c|c|}
\hline $\begin{array}{l}\text { Category 1: Adn } \\
\text { grammar }\end{array}$ & al pronouns described and/or attested several times in the \\
\hline Alyawarra & (Yallop 1977: 112-113) \\
\hline Arabana & (Hercus 1994: 285) \\
\hline Arrernte & (Wilkins 1989: §3.7.3) \\
\hline Bininj Gun-Wok & (Evans 2003a: 246-247) \\
\hline Burarra & (Green 1987: 22-23) \\
\hline Dhuwal & (Wilkinson 1991: 211; Morphy 1983: 83) \\
\hline Diyari & (Austin 1981: 97-98) \\
\hline Djinang & (Waters 1989: 197) \\
\hline Garrwa & (Mushin 2012: 103-108) \\
\hline Gooniyandi & (McGregor 1990: 144-145, 170-171) \\
\hline Gumbaynggirr & (Eades 1979: 313) \\
\hline Guugu Yimidhirr & (Haviland 1979: 104-105, 156) \\
\hline Jingulu & (attestations throughout Pensalfini 2003) \\
\hline Kala Lagaw Ya & (Stirling 2008; Ford \& Ober 1991: 124-126, 130) \\
\hline Kayardild & (Evans 1995: 239-240; Round 2013: 141-142) \\
\hline Kugu Nganhcara & (Smith \& Johnson 2000: 419-420) \\
\hline Kuku Yalanji & (Patz 2002: 119, 202) \\
\hline Kuuk Thaayorre & (Gaby 2006: 287-291, 298-301) \\
\hline Mawng & (Singer 2006: 37-38) \\
\hline Ndjébbana & (McKay 2000: 294) \\
\hline Ngarrindjerri & (Bannister 2004: 66) \\
\hline Ngiyambaa & (Donaldson 1980: 127-129, 229) \\
\hline Nyangumarta & (attestations throughout Sharp 2004) \\
\hline
\end{tabular}




\begin{tabular}{|c|c|c|}
\hline Nyulnyul & \multicolumn{2}{|c|}{ (McGregor 2011: 124-127, 158-159, 405) } \\
\hline Oykangand & \multicolumn{2}{|c|}{ (attestations throughout Sommer 1970) } \\
\hline Rembarrnga & \multicolumn{2}{|c|}{ (attestations throughout Saulwick 2003, McKay 1975) } \\
\hline Tiwi & \multicolumn{2}{|c|}{ (Osborne 1974: 74, Lee 1987: 119, 233-234) } \\
\hline Umpila & \multicolumn{2}{|l|}{ (Hill ms: 5, 13-16) } \\
\hline Umpithamu & \multicolumn{2}{|c|}{ (Verstraete ms \& fieldnotes) } \\
\hline Uradhi & \multicolumn{2}{|l|}{ (Crowley 1983: 371) } \\
\hline Wambaya & \multicolumn{2}{|c|}{ (Nordlinger 1998: 134) } \\
\hline Worrorra & \multicolumn{2}{|c|}{ (Clendon 2000: 237; 464-465) } \\
\hline Yankunytjatjara & \multicolumn{2}{|c|}{ (Goddard 1985: 17, 59-60) } \\
\hline Yandruwandha & \multicolumn{2}{|c|}{ (attestations throughout Breen 2004a, b) } \\
\hline Yanyuwa & \multicolumn{2}{|c|}{ (attestations throughout Kirton 1971, Kirton \& Charlie 1996) } \\
\hline Yawuru & \multicolumn{2}{|c|}{ (Hosokawa 1991: 439-440, 491) } \\
\hline Yir Yoront & \multicolumn{2}{|l|}{ (Alpher 1973: 281) } \\
\hline \multicolumn{3}{|c|}{ Category 2: Uncertain } \\
\hline \multicolumn{3}{|c|}{ Category 2a: Adnominal pronouns not described in the grammar, attested only once or } \\
\hline Dharumbal & Lardil & Yalarnnga \\
\hline Duungidjawu & Rimanggudinhma & Yingkarta \\
\hline Jaru & Wajarri & Yuwaalaraay \\
\hline \multicolumn{3}{|c|}{ Category 2b: Adnominal pronouns not described or attested in the grammar-based on } \\
\hline Atynyamatanha & Nyungar & Wathawurrung \\
\hline
\end{tabular}




\begin{tabular}{|c|c|c|}
\hline Bunganditj & Walmajarri & Yorta Yorta \\
\hline \multicolumn{3}{|c|}{ Category 3: Absent } \\
\hline \multicolumn{3}{|c|}{ Category 3a: Adnominal pronouns certainly absent (no clearly separate $3^{\text {rd }}$ person } \\
\hline Djabugay & Mathi group & Warlpiri \\
\hline Limilngan & Nhanda & Yidij \\
\hline Martuthunira $^{18}$ & Pitta-Pitta & Yindjibarndi \\
\hline \multicolumn{3}{|c|}{ Category 3b: Adnominal pronouns probably absent (not described or attested in the } \\
\hline \multicolumn{3}{|c|}{ grammar, even though we have good descriptions and/or sufficient data) } \\
\hline Alawa & Jaminjung & Paakantyi \\
\hline Bilinarra & Mara & Panyjima \\
\hline Emmi & Marrithiyel & Ritharngu \\
\hline Enindhilyakwa & Ngan'gityemerri & Wardaman \\
\hline Gaagudju & & Warrongo \\
\hline
\end{tabular}

Table 2: Attestations in the sample

\footnotetext{
${ }^{18}$ Martuthunira does have a 3rd person plural pronoun, but with a "very restricted function of serving as a definite anaphor for plural noun phrases" (Dench 1994: 103).
} 


\begin{tabular}{|c|c|c|}
\hline Initial & Fixed & $\begin{array}{l}\text { Burarra (Green 1987: 22) } \\
\text { Dhuwal (Morphy 1983: 83) } \\
\text { Diyari (Austin 2011: 100) } \\
\text { Djinang (Waters 1989: 197) } \\
\text { Gooniyandi (McGregor 1990: 253, 257) } \\
\text { Mawng (Singer 2006: 95, 98) } \\
\text { Ngarrindjerri (Bannister 2004: 66) } \\
\text { Nyulnyul (McGregor 2011: 405) } \\
\text { Tiwi (Osborne 1974: 74, Lee 1987: 108, 121, 233-234) } \\
\text { Uradhi (Crowley 1983: 371) } \\
\text { Wambaya (based on examples throughout grammar) } \\
\text { Yanyuwa (based on examples throughout grammar) } \\
\text { Yawuru (Hosokawa 1991: 491) }\end{array}$ \\
\hline & $\begin{array}{l}\text { More } \\
\text { frequent }\end{array}$ & $\begin{array}{l}\text { Guugu Yimidhirr (Haviland 1979: } 104 \text { mentions initial position, but } \\
\text { counter-examples are found) } \\
\text { Kala Lagaw Ya (Stirling 2008: 177) } \\
\text { Kugu Nganhcara (Smith \& Johnson 2000: 420) } \\
\text { Kuku Yalanji (based on examples throughout grammar) } \\
\text { Ndjébbana (McKay 2000: 294) }\end{array}$ \\
\hline
\end{tabular}

\footnotetext{
${ }^{19}$ Note that an alternative position of the pronoun is possible in Dhuwal, but only when it has a different function. When the adnominal pronoun immediately follows its head (i.e. not necessarily at the right edge), it functions as a number marker (Morphy 1983: 47). See further in section 3.2 below.

${ }^{20}$ An alternative position is available in Gooniyandi, but with a different function (thanks to Bill McGregor (p.c.) for pointing this out to us). When the adnominal pronoun follows the head, it serves as a qualifier (McGregor 1990: 267-270), marking referent modification rather than reference modification (in the sense of Bolinger 1967).
} 


\begin{tabular}{|c|c|c|}
\hline & & Worrorra (based on examples throughout grammar) \\
\hline \multirow[t]{2}{*}{ Final } & Fixed & $\begin{array}{l}\text { Alyawarra (based on examples throughout grammar) } \\
\text { Arrernte (Wilkins 1989: } \S 3.1, \S 3.7 .3 \text { ) } \\
\text { Umpithamu (Verstraete ms: 7) } \\
\text { Yankunytjatjara (Goddard 1985: 60) }\end{array}$ \\
\hline & $\begin{array}{l}\text { More } \\
\text { frequent }\end{array}$ & $\begin{array}{l}\text { Garrwa (Mushin 2012: 103-104) } \\
\text { Yir Yoront (Alpher 1973: 281) }\end{array}$ \\
\hline \multirow[b]{2}{*}{$\begin{array}{l}\text { Either } \\
\text { edge }\end{array}$} & $\begin{array}{l}\text { Syntactic/ } \\
\text { discourse } \\
\text { conditions }\end{array}$ & Umpila (Hill ms: 24-31) \\
\hline & $\begin{array}{l}\text { Preference/ } \\
\text { conditions } \\
\text { unclear }\end{array}$ & $\begin{array}{l}\text { Arabana } \\
\text { Bininj Gun-wok } \\
\text { Gumbaynggirr } \\
\text { Jingulu } \\
\text { Kayardild (Evans 1995: 235; possibly preferred initially) } \\
\text { Nyangumarta } \\
\text { Oykangand } \\
\text { Rembarrnga } \\
\text { Yandruwandha }\end{array}$ \\
\hline \multicolumn{2}{|l|}{ Other } & $\begin{array}{l}\text { Kuuk Thaayorre: pronoun not necessarily adjacent, not part of NP } \\
\text { (Gaby 2006: 289-291) }\end{array}$ \\
\hline
\end{tabular}




\begin{tabular}{|l|l|}
\hline & $\begin{array}{l}\text { Ngiyambaa: pronoun enclitic, not part of NP, but always preceding it } \\
\text { (Donaldson 1980:127-129) }\end{array}$ \\
\hline
\end{tabular}

Table 3: Position of adnominal pronoun w.r.t. nominal expression 


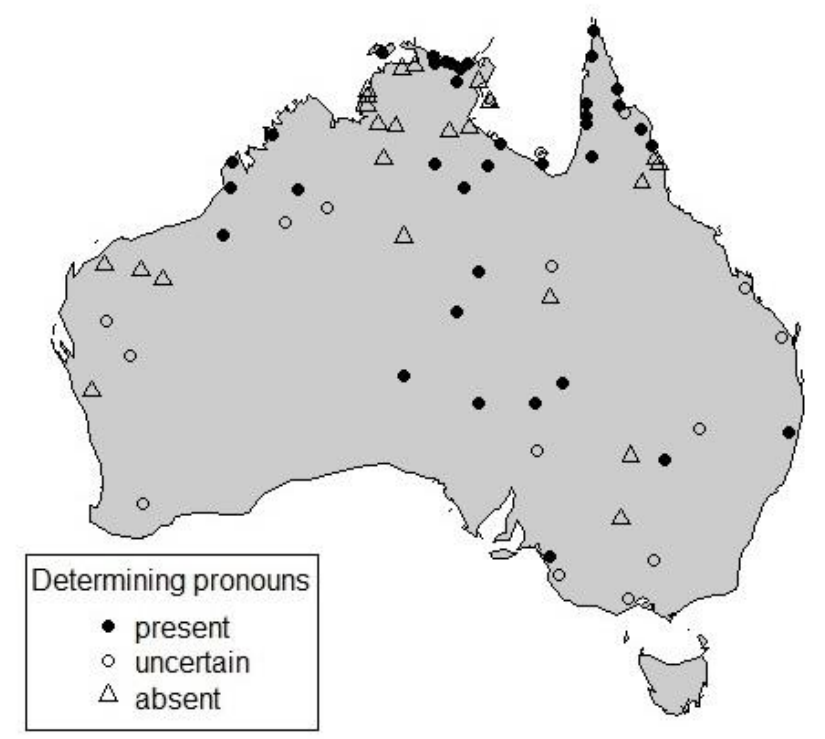

Figure 1: Personal pronouns with determining functions in the sample (locations are based on Bowern 2011a) 